\title{
Do metaphors evolve? The case of the social organism
}

\section{Mouton, Nicolaas T.O.}

Published in:

Cognitive Semiotics

\section{Publication date:}

2013

Citation for published version (APA):

Mouton, N. T. O. (2013). Do metaphors evolve? The case of the social organism. Cognitive Semiotics, V(1-2), 312.

\section{General rights}

Copyright and moral rights for the publications made accessible in the public portal are retained by the authors and/or other copyright owners and it is a condition of accessing publications that users recognise and abide by the legal requirements associated with these rights.

- Users may download and print one copy of any publication from the public portal for the purpose of private study or research.

- You may not further distribute the material or use it for any profit-making activity or commercial gain.

- You may freely distribute the URL identifying the publication in the public portal.

Take down policy

If you believe that this document breaches copyright please contact rucforsk@kb.dk providing details, and we will remove access to the work immediately and investigate your claim. 


\title{
Nico Mouton
}

\author{
Roskilde University \\ Do Metaphors Evolve? The Case of the Social \\ Organism
}

\begin{abstract}
A long line of philosophers and social scientists have defended and extended the curious idea that collective entities - states and societies, cities and corporations - are biological organisms. In this article, I study a few short but spectacular episodes from the history of that metaphor, juxtapose mappings made in one era with correspondences conjured in other epochs, and reflect upon the reasons why they differ. By adopting a historical perspective on the process whereby the notion of a 'social organism' evolved from its relatively simple beginnings in ancient philosophy to its rather complex manifestations in the modern social sciences, I hope to show that there are good reasons to reconsider both Lakoff's decree that metaphors 'should not be thought of as processes' and his declaration that they should instead be seen as consisting of 'a fixed pattern of ontological correspondences across domains' (Lakoff, 1993:210, emphasis added). Building on ideas about metaphor that emerged during the Nineteenth Century, I argue that what may initially appear to be a fixed pattern of projections is often better understood as a temporary station in a fluid process.
\end{abstract}

Keywords: metaphor, intellectual history, conceptual evolution, historical situatedness, social organism.

\section{INTRODUCTION}

'There is here the possibility for a new kind of inquiry - an intellectual history which would consider not the manifest content of theories, but the development of their underlying metaphors' (Schön 1963:192).

'History, like anthropology, specializes in the discovery and display of human variety, but in time rather than space. It reveals that even our own ancestors lived lives stunningly different from ours' (Sewell 1997:38).

Already in antiquity, it was common to conceptualize collective entities as biological organisms and to portray their parts - patricians and plebeians, soldiers and statesmen, peasants and priests - as interdependent organs. Thus, Plato argued that a wound to any of its parts makes the whole city suffer (Republic 462c-d); Aristotle postulated that disproportionate growth of any part of the body politic causes it either to perish or 'take the form of another animal' (Politics 1302b-1303a); Plutarch asserted that an eloquent parvenu named Menenius Agrippa prevented a plebeian revolt by persuading the

Address for correspondence: Department of Communication, Business, and Information Technologies, Roskilde University, Universitetsvej 1, DK-4000 Roskilde, Denmark; email: ntom@ruc.dk. 
crowd that society is an organism, that the patricians are society's stomach, and that it would be selfdefeating for the plebeian organs to conspire against the patrician stomach (Plutarch 1803:81).

Subsequently, novel extensions and new elaborations of that ancient metaphor surfaced in texts as diverse as Shakespeare's Coriolanus (ca. 1605) and Spencer's The Social Organism (1860); Davanzati's A Discourse Upon Coins (1588) and Durkheim's The Division of Labour in Society (1893); Harrington's The Commonwealth of Oceana (1656) and Huxley's Administrative Nihilism (1871); Rousseau's Social Contract (1762) and Radcliffe-Brown's On the Concept of Function in Social Science (1935). Many of the metaphor's manifestations in these texts contain traces - some subtle, others obvious - of the era in which they emerged.

Thus, during the Seventeenth Century, men like Hobbes and Harrington dissected the social organism in a manner that flaunted their familiarity with Harvey's findings (Cohen 1994). Consider Harrington's proposal that 'parliament is the heart which, consisting of two ventricles, the one greater and replenished with a grosser store, the other less and full of a purer, sucketh in and gusheth forth the life blood of Oceana by a perpetual circulation' (Harrington 1656/1737: 161). Such passages show that 'Harrington's appreciation of the Harveyan physiology was not limited to generalities but invoked detailed features of the new biological science' (Cohen 1994: 200).

Similarly, during the Nineteenth Century, Spencer was quick to exploit the new knowledge that was then emerging in various branches of biology. It enabled him to extend and elaborate the social organism metaphor in ways that would not have been possible, as Spencer acknowledged, 'in the absence of physiological science, and especially of those comprehensive generalizations which it has but lately reached' (Spencer 1860/1996: 269). Consider his convoluted account of how a nervous system gradually emerges during the evolution of the social organism:

Thus far in comparing the governmental organization of the body-politic with that of an individual body, we have considered only the respective coordinating centres. We have yet to consider the channels through which these coordinating centres receive information and convey commands. In the simplest societies, as in the simplest organisms, there is no 'internuncial apparatus', as Hunter styled the nervous system. Consequently, impressions can be but slowly propagated from unit to unit throughout the whole mass. The same progress, however, which, in animal-organization, shows itself in the establishment of ganglia or directive centres, shows itself also in the establishment of nerve-threads, through which the ganglia receive and convey impressions and so control remote organs. And in societies the like eventually takes place. After a long period during which the directive centres communicate with various parts of the society through other means, there at last comes into existence an 'internuncial apparatus', analogous to that found in individual bodies. The comparison of telegraph-wires to nerves is familiar to all (Spencer 1860/1996: 305-306).

It is sometimes mistakenly suggested that the metaphor died roughly three centuries ago (Hale 1973:70). The reports of its demise are wildly exaggerated. Modern mutations of the ancient analogy between organisms and collective entities still appear frequently in publications like The American Journal of Sociology, Administrative Science Quarterly, and American Sociological Review. Browse through any of those journals, and you are bound to come across articles with telling titles like Organizational birth frequencies: An empirical investigation (Pennings 1982), The liability of 
newness: Age dependence in organizational death rates (Freeman et al. 1983), A time to grow and a time to die: Growth and mortality of credit unions in New York City, 1914-1990 (Barron et al. 1994), or Populations, natural selection, and applied organizational science (McKelvey \& Aldrich 1983). Again, it is not difficult to discern traces of the era in which these articles were written. The references to 'birth frequencies' and 'death rates' in entire 'populations of organizations' - not to mention the most obvious clue, 'natural selection' - reflect a style of reasoning that gradually evolved among biologists during the Nineteenth Century, and first reached the social sciences during the Twentieth Century. ${ }^{1}$ Admittedly, one often finds references to the 'birth' of states or the 'death' of societies in earlier treatises like Shakespeare's Coriolanus or Rousseau's Social Contract; Rousseau devoted a whole chapter to a discussion of 'The death of the body politic' (1997:109ff). Yet those terms, in those texts, never collocate with 'rates' or 'frequencies'. It is easy to find other examples of extensions and elaborations that carry overt traces of their origins. Even if I told you nothing about when, where, and by whom the following statement was made, the proposed mapping would reveal that we are dealing with a text that could not have been written before the Twentieth Century: 'the analogue to a regulator gene in organizations is a higher-order coordinating routine' (Hannan \& Freeman 1986:57).

\section{WHAT IS (NOT) AT STAKE}

The mere observation that philosophers, sociologists, or political scientists regularly resort to metaphor is hardly news. Already in the late Nineteenth Century, social scientists were commenting that metaphor and analogy - in the lofty words of Lester Ward - 'inheres in the man of science as well as in the artist or the poet, and it cannot be suppressed. It lives alike in the savage, the untutored peasant or shepherd, in the half-educated classes of modern society, and in the best stored minds of our day' (Ward 1897:258). Returning to the topic shortly before he became the first president of the American Sociological Association, Ward pithily added that 'the passion for analogies had been at once one of the most powerful stimuli to research, and one of the greatest sources of error in the history of science' (Ward 1902:480).

Roughly two decades later, just as the logical positivists of the Vienna Circle were launching their project, Morris Cohen insisted that metaphors 'play a large part in opening up new fields of science' (1923:479) and illustrated his claim with examples from philosophy, psychology, and physics. Commenting on those examples, Cohen contended that 'many of the passages first taken as literal truths are really metaphors to which we have become accustomed'; claimed that 'to eliminate all

\footnotetext{
${ }^{1}$ While Nineteenth Century sociologists, in their accounts of 'social evolution', often spoke about the birth of societies and occasionally about their death, they never referred to 'birth frequencies' or 'mortality rates'. As Robert Nisbet rightly noted, 'it is often said, by those unfamiliar with the history of ideas, that the social evolutionists of the nineteenth-century were applying to institutions the idea of biological evolution formulated by Darwin... no such dependence is, in fact, to be found' (Nisbet 1970: 356-357). The crucial difference, he argued, is that 'the biological theory became (very considerably in its Darwinian statement, wholly after it was fused with Mendel's great researches) a populational and statistical theory', whereas the sociologists' theory of social evolution was 'a typological construction' (Nisbet 1975: 162, emphasis added). That is the main reason why their texts contain no references to birth frequencies or death rates.
} 
metaphors is impossible' when we 'try to express general considerations of a novel or unfamiliar character'; and concluded that 'metaphors are not merely artificial devices for making discourse more vivid and poetical, but are also necessary means for the apprehension and communication of new ideas' (Cohen 1923: 478; see also e.g. Pepper 1928, 1935).

It took the analytic philosophers, who dominated debates about metaphor until a few decades ago, quite some time to rediscover those insights, but even Donald Davidson eventually decided that 'metaphor is a legitimate device not only in literature but in science, philosophy, and the law' (1978: 33). That is probably just about the only remark in Davidson's paper that would not provoke any controversy among the cognitive linguists who now dominate discussions about metaphor. In short, there does not seem to be a need any longer to defend the claim that scientists use metaphors. As Mark Johnson and Diego Fernandez-Duque (2002: 26) noted in the conclusion to their study of the role of conceptual metaphors in psychological theories of attention: 'metaphor in scientific reasoning is a fact'.

To say that metaphor in scientific reasoning is a fact does not mean, of course, that nothing remains to be said about that fact. In this paper, I would like to re-introduce issues that featured prominently in late Nineteenth and early Twentieth Century discussions of metaphor in scientific reasoning. Thinkers from that era did not merely anticipate many of our current concerns: they also addressed themes that were subsequently displaced from the agenda and have only started to re-appear very recently.

Crucially, they were interested in the process whereby metaphors such as the 'social organism' evolved over time. From a slightly different angle, one could say that they viewed such metaphors from a historicist perspective, in roughly the sense of 'historicism' that Maurice Mandelbaum had in mind: 'historicism is the belief that an adequate understanding of the nature of any phenomenon, and an adequate assessment of its value, are to be gained through considering it in terms of the place it occupied, and the role which it played, within a process of development' (Mandelbaum 1971: 42).

That they viewed metaphor from this perspective should not come as a surprise. As Nisbet (2002: 103) notes, the notion of development was 'omnipresent as an idea or theme in nineteenthcentury thought'; thinkers from that era tried to discover the 'laws of motion' underlying phenomena as diverse as culture and capitalism, language and law, science and society, institutions and ideas. When they turned their attention to metaphors such as the idea that society is an organism, they quite naturally assumed that, in order to understand its nature, one had to understand its history.

I will excavate some of the relevant writings in due course. For now, suffice it to say that the question of how metaphors evolve did not completely disappear from the research agenda during the Twentieth Century. Consider Donald Schön's Displacement of Concepts (1963), which was subsequently re-published with the more telling title The Invention and Evolution of Ideas (1967). Schön tried, inter alia, to delineate various stages in the development of metaphors, from 'the first establishment of a symbolic relation between old and new', through the transposition of 'more and 
more concepts from the old concept cluster to the new situation', to the eventual attempts to correct the excesses of the initial phases (1963: 54-55). In his concluding remarks, Schön noted that 'there is here the possibility for a new kind of inquiry - an intellectual history which would consider not the manifest content of theories, but the development of their underlying metaphors' (1963: 192).

That Schön thought he had stumbled upon 'a new kind of inquiry' indicates that his precursors had been forgotten, and therefore he needed to re-invent a kind of inquiry for which there were plenty of promising precedents. That is not particularly surprising: after all, at the time, debates about metaphor were dominated by analytic philosophers, whose analyses of metaphor invariably remind one of why they are 'widely regarded the very antithesis of historical sensibility' (Hacking 2002: 51). Schön was swimming against a very strong ahistorical stream.

These issues are beginning to (re-)appear in the cognitive linguistics community. In recent years, Zinken, Hellsten, and Nerlich have investigated how metaphors 'evolve in historical time' (2007: 368); Musolff has inquired whether "the notion of "(conceptual) evolution" [can] be applied to the development and variation of metaphors over time' (2004: 55); Frank has inspected 'discourse metaphor formations' that appear to be 'highly entrenched, albeit constantly changing, entities' with 'a rich social and cultural history' (2007: 216).

Just as Schön was swimming against an ahistorical stream, it seems to me that these scholars are struggling against a rather strong ahistorical current of thought. For example, on those rare occasions when explicit references to the historical contingency of conceptual systems appear in Lakoff's writings, that contingency is dismissed as being at odds with the defining assumptions of Conceptual Metaphor Theory.

Thus, Lakoff observes that 'much of continental philosophy, observing that conceptual systems change through time, assumes that conceptual systems are purely historically contingent, that there are no conceptual universals. Though conceptual systems do change through time, there do, however, appear to be universal, or at least very widespread, conceptual metaphors'. (Lakoff, 1993:248-249). He argues that this emphasis on historical contingency is one of the ways in which 'much of continental philosophy and deconstructionism is ... characterized by defining assumptions at odds with the contemporary theory of metaphor' (Lakoff 1993: 248). After this brief acknowledgement that some unidentified European philosophers reckon that 'conceptual systems change through time', and the accompanying admission that there may be some limited truth to the idea even though it is at odds with the defining assumptions of Conceptual Metaphor Theory, Lakoff did not really address the question again, as far as I can tell.

Apart from such explicit dismissals of historical perspectives, the very possibility of conceptual evolution is often implicitly denied in more subtle ways. To see what I have in mind, consider the following remarks by leading proponents of a prominent version of Conceptual Metaphor Theory. Lakoff explicitly decrees that metaphorical mappings 'should not be thought of as processes' but rather as 'a fixed pattern of ontological correspondences across domains' (Lakoff 1993: 210, emphasis 
added; see also e.g. Lakoff 1993: 245; 2008:24, 28). Zoltán Kövecses expressly declares that metaphors consist of 'a static and highly conventionalized system of mappings' (Kövecses 2006: 201, emphasis added). Lakoff proposes the paradoxical position that a novel mapping - or rather, what appears to be a novel mapping - is always already embedded in a pre-existing 'static mapping pattern', the 'unused parts' of which merely needed to be 'activated' (Lakoff 1993: 210-211, emphasis added; Lakoff \& Johnson 1980: 52-53).

These claims are incompatible with the type of historical perspective proposed by scholars like Nerlich, Musolff, and Frank. More specifically, Lakoff's claim that metaphors 'should not be thought of as processes' seems irreconcilable with Zinken, Hellsten, and Nerlich's claim that metaphors 'evolve in historical time' (after all, to say that metaphors 'evolve' surely means that they should be thought of as processes); Lakoff's contention that metaphors consist of 'fixed patterns' seems incommensurable with Frank's claim that metaphors are 'constantly changing entities'; and Kövecses' conception of metaphors as 'static systems' seems incompatible with Musolff's focus on the 'development and variation of metaphors over time'. The main problem with the dominant version of Conceptual Metaphor Theory, from this perspective, is that it 'does not account for the flexible evolution of metaphors in use' (Zinken et al. 2007: 376).

One potential solution would simply be to say that the two factions are talking about different types of metaphors. This is the option that Zinken, Hellsten, and Nerlich take when they distinguish between 'conceptual metaphors' and 'discourse metaphors': 'conceptual metaphors are considered universal [and] independent of time while discourse metaphors change with the on-going discourses' (2007: 368). ${ }^{2}$ While it is not difficult to understand the motivation for such a distinction, it does not seem particularly satisfactory: Occam's advice that entities ought not to be multiplied beyond necessity is still sound.

An alternative way to frame the conflict between the two conceptions is contained in one of the critics' references to 'a relatively stable metaphorical projection that functions as a key framing device within a particular discourse over a certain period of time' (Zinken et al. 2007: 363). The key phrases here are 'relatively stable', 'a particular discourse', and 'over a certain period of time'. In contrast to Lakoff's references to 'fixed' mappings, which are not accompanied by any qualifications, this formulation suggests that some mappings might remain fairly fixed over relatively long periods of time, while others might be more fluid and fleeting. This removes the need to postulate two different kinds of entities and makes it possible to settle the dispute by empirical means rather than conceptual gerrymandering.

\footnotetext{
${ }^{2}$ It is not quite clear whether the authors actually believe that there are two kinds of metaphor. Later in the article, they make a number of remarks like the following: '[discourse metaphors are] very frequent and crossculturally wide-spread, while the link between hypothesised abstract metaphor schemas like PERSISTING IS REMAINING ERECT and observable linguistic behaviour is much weaker' (Zinken et al. 2007: 375). This sounds like a polite way of saying that one is sceptical about the existence of the hypothesized entities and that there is probably only one kind of metaphor after all.
} 
To investigate empirically whether mappings are fixed or fluid over time, and why, one needs a case with a fossil record rich enough to facilitate fairly detailed comparisons of how the same metaphor was construed in different epochs. Since the 'social organism' metaphor has been around for more than two thousand years, it is eminently suitable for such a study.

In principle, the best way to go about the task would be to adopt Arthur Lovejoy's classical approach, which involved 'the study of the (so far as possible) total life history of individual ideas' (1948: 9, emphasis added). More specifically, Lovejoy insisted that an idea should be followed across the boundaries separating different cultures and different epochs, 'through more than one - ultimately, indeed, through all - of the provinces of history in which it figures in any important degree, whether those provinces are called philosophy, science, literature, art, religion, or politics' (Lovejoy, 1948:15). Moreover, he insisted that the historian should pay attention to the different facets that an idea exhibited at different stages of its history, to the different roles that it played on the historic scene, to its different alliances and conflicts with other ideas, to whether successive users adopted different attitudes towards it. One might add that, if the idea happens to be a metaphor, it would obviously make sense to also pay attention to whether the metaphor was extended in different directions during different eras, and then identify the difference(s) that made the difference.

In practice, unfortunately, it is not feasible to do all of this in the context of a journal article. To reconstruct the 'total life history' of the social organism, if it can be done at all, would require a rather long dissertation. Instead, a few short episodes from the metaphor's long history will have to suffice. I will focus initially on a spectacular episode that spanned from roughly the middle of the Nineteenth Century to the beginning of the Twentieth, and that took place primarily in the nascent disciplines of sociology and Staatswissenschaft. ${ }^{3}$ As the story proceeds, I will gradually begin to contrast the mappings that were made during this period, in this particular discourse, with alternative sets of correspondences conceived during other eras.

Before I present the episode, however, allow me briefly to reconstruct Nineteenth Century reflections about metaphor. It so happens that the Nineteenth Century episode in the history of the social organism metaphor overlapped with some rather insightful meta-reflections about the role of metaphor in scientific reasoning. Indeed, many of those Nineteenth Century reflections about metaphor were prompted by the pervasiveness and prominence of the social organism metaphor in Nineteenth Century social scientific discourse. Their abstract meta-reflections about metaphor might make it easier to grasp what was distinctive about their extensions and elaborations of the concrete metaphor.

\footnotetext{
${ }^{3}$ I will concentrate primarily on sociology, to keep the narrative relatively simple. Coker (1910) provided a comprehensive overview of the various 'organismic' theories of the state that were advanced by Nineteenth Century political scientists like Karl Zacharia and Johann Bluntschli. He also included a long chapter on the sociologists' social organism (Coker 1910: 116-190). Shorter commentaries by contemporaries can be found in e.g. (Ward 1897, 1902, 1907) and (Giddings 1896).
} 


\section{FIN DE SIÉCLE PERSPECTIVES ON THE HISTORICAL SITUATEDNESS OF METAPHOR}

Throughout the late Nineteenth and the early Twentieth Century, the really interesting conversations about metaphor did not take place in the two disciplines - rhetoric and philosophy - that traditionally hosted them. Instead, the most insightful discussions were initiated by scholars from disciplines like sociology and economics. Typically, they did not write books that were explicitly and exclusively about metaphor as we now do. (This might explain why their contributions never receive credit in contemporary reconstructions of the history of theories of metaphor.) Rather, their reflections on metaphor usually emerged in the context of attempts to understand the development of a particular discipline, school, or theory. In pursuit of that goal, the commentator's emphasis often gradually shifted from the development of the theory to the process whereby the analogy underlying it was extended and elaborated. Lester Ward's commentary about the development of the 'biological school' of fin de siècle sociology constitutes a good example. It contains numerous remarks like the following: 'it is remarkable how far it is possible to carry [the analogy between societies and organisms] when a large number of acute minds are fixed upon it for a considerable time' (Ward 1902: 484).

The three distinct claims contained in that comment - namely, that the relevant metaphor was continuously 'carried further', that it was carried further by 'a large number of acute minds', and that it took those acute minds 'a considerable time' to carry it as far as they did - add up to an account of metaphor that anticipates many of our current concerns. Ward's observation that it involved 'a large number of acute minds' neatly captures the core idea of what is now called 'sociocultural situatedness': namely, that 'individual minds and cognitive processes are shaped by their being together with other embodied minds' (Frank 2007: 1). The observation that it took those minds 'a considerable time' adds another dimension - call it 'historical situatedness' - which clearly suggests that we are, pace Lakoff, dealing with a process. Ward gave us a number of other reasons to think that metaphors do not necessarily settle down into 'fixed patterns of correspondences'. As I will show in a later section, he demonstrated quite convincingly that the 'acute minds' of Nineteenth Century sociology's 'biological school' rarely agreed about mappings; they competed vigorously to extend the metaphor in new directions, contested vehemently the extensions proposed by others, and thereby kept the theory based on the metaphor in constant motion.

In other cases - and these are the most interesting - scholars who were trying to extend and elaborate a particular metaphor gradually began to reflect on what they were doing. In the process, they came up with promising fragments - but no finished products - of a fairly plausible theory of metaphor. For example, Herbert Spencer was patently not merely aware that he was relying on a metaphor when he wrote texts like The Social Organism (1860); he had a fairly sophisticated conception of what metaphors are, how they work, and how they can be exploited most effectively.

This is reflected in a considerable amount of explicit meta-communication about his use of metaphor. Thus, he explicitly drew attention to what he deemed the main similarities between the 
source and target domains: 'societies agree with individual organisms in four conspicuous peculiarities' (1996: 272) ${ }^{4}$; to the respects in which the metaphor may not hold: 'the leading differences between societies and individual organisms are these...' (1996: 273); to mappings that may require a certain amount of tinkering if they are to work: 'a further complication of the analogy is at hand' (1996: 280); to mappings he deemed to be conventional: 'the comparison of telegraph-wires to nerves is familiar to all' (1996: 306); to extensions and elaborations that he came up with, and deemed novel: 'it applies, however, to an extent not commonly supposed' (1996: 306); and to the open-endedness of the process: "carrying out the comparison in detail, we find that these major analogies involve many minor analogies, far closer than might have been expected. Others might be added' (1996: 306-307). Once one begins to pay attention to such remarks, the outlines of a fairly coherent theory of metaphor become visible. One of his remarks is especially interesting in the present context:

A perception that there exists some analogy between the body politic and a living individual body, was early reached; and has from time to time re-appeared in literature. But this perception was necessarily vague and more or less fanciful. In the absence of physiological science, and especially of those comprehensive generalizations which it has but lately reached, it was impossible to discern the real parallelisms (Spencer 1996: 269, emphasis added).

One may well question whether the 'parallelisms' Spencer claimed to have discerned were indeed more 'real' than the ones postulated by his predecessors; it would have been more apt simply to say that they were different. For that matter, it is not clear what exactly it means to say that a parallelism is 'real' to begin with. Despite these difficulties, Spencer was onto something significant when he suggested that the rapid developments in scientific fields such as physiology and embryology during the Nineteenth Century enabled him to make novel mappings between the two domains that earlier users of the metaphor would have found 'impossible to discern'.

This contention contradicts Lakoff's claim that a pre-existing 'static mapping pattern' is always already available for activation. It seems to me that Spencer was right in this regard, and I will spend considerable effort in later sections of this article to explain why. (If I postpone the issue, it is because it would arguably be more effective to show why some of the mappings that Spencer proposed could not have emerged earlier than the Nineteenth Century than to merely say so.) Suffice it for now to say that, from Spencer's perspective, earlier users of the same metaphor could not have made the same mappings, because the necessary knowledge was not yet available to them.

While such reflections were most common among sociologists, similar remarks surfaced in disciplines as diverse as physics and economics. Thus, the physicist Norman Campbell cogently noted that metaphors are 'an utterly essential part of theories' not only in the initial phase of invention, but also in the subsequent development of those theories (Campbell 1920:129). From Campbell's point of view - as Mary Hesse pointed out - a scientific theory was decidedly 'not a static museum piece, but

\footnotetext{
${ }^{4}$ He went about this quite systematically: the text contains fifty uses of the words 'analogy', 'analogies', 'analogues', 'analogous', and 'analogously'.
} 
is always being extended and modified to account for new phenomena'; this process is propelled by a persistent probing of those aspects of the underlying analogy 'about which we do not yet know whether they are positive or negative analogies' (Hesse 1966: 4, 9; emphasis added). The little word 'yet' does a lot of work in this formulation: it emphasizes the temporal element that is so often missing from more recent theories; the users of a metaphor often do not know, at any specific stage in its development, where it may lead next. Without the dubious benefit of hindsight, it would not seem plausible to say that they merely activated the 'unused parts' of a 'static mapping pattern' that had been there all along (Lakoff \& Johnson 1980: 52-53, Lakoff 1993: 210-211).

Elsewhere, economists like Alfred Marshall began to reflect upon their reliance on metaphorical reasoning and came to similar conclusions. ${ }^{5}$ The best angle from which to approach Marshall's conception of metaphor is to consider an observation he made at the outset of Principles of Economics: 'economic conditions are constantly changing, and each generation looks at its own problems in its own way' (1891: ix). This deceptively simple depiction of the dismal science's historicity also surfaced in Marshall's statements about figurative economic thought.

Thus, he faulted his fellow fin-de-siècle economists for their failure to free themselves from the inference patterns that their predecessors had imported from physics, urged them to develop their own metaphors by borrowing from biology instead, and in the process introduced very perceptive insights into the evolution of economists' metaphors:

It has been well said that analogies may help one into the saddle, but are encumbrances on a long journey. It is well to know when to introduce them, it is even better to know when to stop them off. Two things may resemble one another in their initial stages; and a comparison of the two may then be helpful: but after a while they diverge; and then the comparison begins to confuse and warp the judgment. There is a fairly close analogy between the earlier stages of economic reasoning and the devices of physical statics. But is there an equally serviceable analogy between the later stages of economic reasoning and the methods of physical dynamics? I think not. I think that in the later stages of economics better analogies are to be got from biology than from physics; and consequently, that economic reasoning should start on methods analogous to those of physical statics, and should gradually become more biological in tone (Marshall 1898: 39).

The evaluative facet of this formulation - 'better analogies are to be got from biology than from physics' - is not what makes the passage interesting. Indeed, it prevents one from perceiving a more fundamental aspect of Marshall's account: namely, his assumption that metaphors evolve. Consider again the claim that 'two things may resemble one another in their initial stages; and a comparison of the two may then be helpful: but after a while they diverge; and then the comparison begins to confuse and warp the judgment'. Clearly, he would not have agreed with Lakoff that metaphors 'should not be thought of as processes'. On the contrary: from Marshall's perspective, metaphors should be seen as involving two distinct processes. First, the things being compared are in perpetual motion: 'two things may resemble one another in their initial stages... but after a while they diverge'. Second, the act of

\footnotetext{
${ }^{5}$ I discuss Marshall's views in considerably more detail in (Mouton 2012). For present purposes, I will just summarize the most salient features of the framework he came up with. As an aside, Marshall was strongly influenced by Spencer and explicitly acknowledged that influence (Marshall 1891: xiv).
} 
comparing them is also a dynamic affair: 'then the comparison begins to confuse and warp the judgment'.

The mere mention of 'comparison' will probably cause some contemporary scholars to dismiss Marshall's observations as outdated. As Fogelin (1994: 23) notes, it has become 'almost mandatory for writers on metaphor to begin by rejecting a similarity or comparativist account of them'. Yet there are still cogent defences of similarity-based theories (e.g. Gentner et al. 2001), and I will try to show that at least some of the correspondences that constituted the Nineteenth Century version of the social organism metaphor were indeed based on similarities rather than, say, 'experiential correlations'.

More importantly, Marshall's basic point about the dynamic nature of metaphor can be translated into contemporary terminology without undue difficulty: a source domain such as 'biological organisms' is not static; a target domain such as 'societies' is not fixed; therefore, the mappings between them are likely to change constantly.

Approached from a somewhat different angle, Marshall's account can be seen as an early version of the familiar claim that 'an era is best known by the metaphors it keeps' (Landau 1972: 84). However, as I have argued elsewhere (Mouton 2012), this idea can be interpreted in two quite different ways, only one of which is plausible.

First, it could be taken to mean that, in studying the history of a discipline's metaphors, one should expect to encounter generational shifts characterized by neat conversions to new source domains. Yet it rarely happens that an entire generation rejects the metaphors it inherits, and replaces them with a different set of mappings based on a different source domain. Not even the development of Marshall's own thought fits this formula. Thus, he admitted that 'biological conceptions are more complex than those of mechanics; a volume on Foundations must therefore give a relatively large place to mechanical analogies; and frequent use is made of the term 'equilibrium', which suggests something of statical analogy' (1920: 19).

There is a second, more plausible, sense in which one could say that an era is best known by the metaphors it keeps. While the first interpretation holds that different generations prefer different source domains, the second construal shifts focus to the way different generations understand and unpack the same source domain in different ways. From this perspective, it is plausible to expect that most extensions and elaborations of a metaphor will contain subtle traces of the era in which they emerged. I will give plenty of examples in later sections of this paper. For now, I would merely like to add that, despite the problematic aspects of Marshall's account, he made an interesting contribution merely by raising the question whether an era is best known by the metaphors it keeps.

Hopefully this brief tour gives readers unfamiliar with the era a basic feel for what late Nineteenth and early Twentieth Century thinkers had to say about metaphor. However, the best way to get a more solid grasp on the issues at stake is to look at a concrete case. 


\section{THE BIOLOGICAL SCHOOL OF NINETEENTH CENTURY SOCIOLOGY}

The idea that societies are organisms featured prominently in the treatises of famous sociologists such as Auguste Comte and Herbert Spencer. It was equally pronounced in the tracts of largely forgotten figures like Albert Schäffle and Rene Worms. As the first president of the American Sociological Association put it in his survey of fin-de-siècle sociology, 'the biological school is certainly just now the most earnest, vigorous, and aggressive' (Ward 1902: 479). Ward initially asserted that the school's defining feature was simply its tendency to look upon human society 'as an organism in strict analogy with an animal or vegetable organism' (1902: 479); but he soon acknowledged that 'the general idea of a social organism is very old' (1902: 482). What distinguished the biological school of Nineteenth Century sociology was rather the exceptional extent to which its members extended and elaborated the metaphor: 'they have pursued it, one would suppose, to its utmost limits' (1902:480).

While they undeniably pushed the metaphor rather far, it would arguably have been more correct to say that they pursued it as far as it could go in the Nineteenth Century (and maybe not even quite that far). Thus, while their Twentieth Century counterparts have made considerable effort to find 'an analogue to the genetic structure that reproduces biotic forms' (Hannan \& Freeman 1986: 55), the very question whether societies have 'genes' could not have been posed in the Nineteenth Century, for the simple reason that not even the great Darwin knew anything about genes. Put differently, if an innovative Nineteenth Century sociologist turned to biology in search of novel 'candidates for truth or falsehood', to borrow Ian Hacking's felicitous phrase (2002: 160), he would not have found anything like the gene in the source domain, always already in place to be projected onto the target domain. It first had to be discovered by Mendel and then rediscovered by De Vries and Correns before it could become a candidate for projection. Some Nineteenth Century sociologists under the sway of biology were quite aware that they had not pursued the metaphor to its 'utmost limits' but merely to the limits imposed by what was (not) known at the time. I will discuss their perspective in detail later in this essay. Let me set that issue aside for a moment, however, and first focus on the mappings that Ward had in mind when he remarked that 'it is remarkable how far it is possible to carry such a theory when a large number of acute minds are fixed upon it for a considerable time' (Ward 1902: 484).

To prove his point, Ward provided a catalogue of the correspondences postulated by members of the biological school. Interestingly, he decided to 'omit the fanciful analogies of Hobbes and other early writers, and limit the enumeration to such as have been more or less seriously proposed by modern sociologists' (Ward 1902: 484). That early writers' extensions and elaborations of the metaphor appeared more 'fanciful' to Ward than the ones that were 'seriously proposed' by his contemporaries hints at the historical situatedness of the metaphor's various manifestations. Had he paid closer attention to the mappings proposed by early writers, and had he then compared those mappings to the correspondences 'seriously proposed' by the biological school of his own day, Ward would have discovered complex patterns of indebtedness and innovation. Even so, the list he came up with is still interesting and useful. The following small selection of entries from Ward's (1902: 484- 
486) catalogue of correspondences serves to indicate just how far, and in what curious directions, the various proponents of the metaphor had extended and elaborated it by $1902:^{6}$

- 'The lower societies represent the segmented type of animals; higher types take on the structure of the anthropoids'.

- 'The circulating mass of commodities in society constitutes its blood'.

- $\quad$ 'Roads, railroads, water ways, etc., constitute the blood-vessels of society'.

- 'Money is the homologue of the blood corpuscles'.

- The counterpart of the cell is

- $\quad$ The individual.

- $\quad$ The reproductive couple, man and woman.

- $\quad$ The trio, man, woman, and child.

- The family.

- The clan.

- $\quad$ 'Corporations are social glands'.

- 'The economic operations of society (production, distribution, exchange, consumption) constitute its nutritive processes (mastication, deglutition, digestion, assimilation)'.

- 'Colonization is social reproduction'.

- 'Persons who go from one society to another are analogous to leucocytes and spermatozoa'.

- Subordinate governments, as of provinces, departments (in France), states (of the United States), counties, municipalities, etc., represent the hierarchy of ganglia of the developed nervous system'.

- $\quad$ 'History is social memory'.

- 'Government is the homologue of the brain'.

- $\quad$ 'Telegraph wires correspond to nerve fibers'.

Ward continued in the same vein for three densely packed pages and then gave up, noting that 'it is, of course, obvious to anyone who has followed the literature on this subject that the above list by no means exhausts the stock of specific analogies that have been pointed out between society and an organism' (Ward 1902: 486). For present purposes, however, it will serve just fine. Allow me to further simplify a complex state of affairs by forcing the most common correspondences on Ward's list into a deceptively neat visual representation (see Figure 1).

\footnotetext{
${ }^{6}$ To avoid confusion, note that Ward compiled his list by collecting examples from a variety of texts written by different members of the biological school. Not all of these correspondences were championed by all members of the school, and they often contradicted one another. I will discuss the issue in more detail in due course.
} 


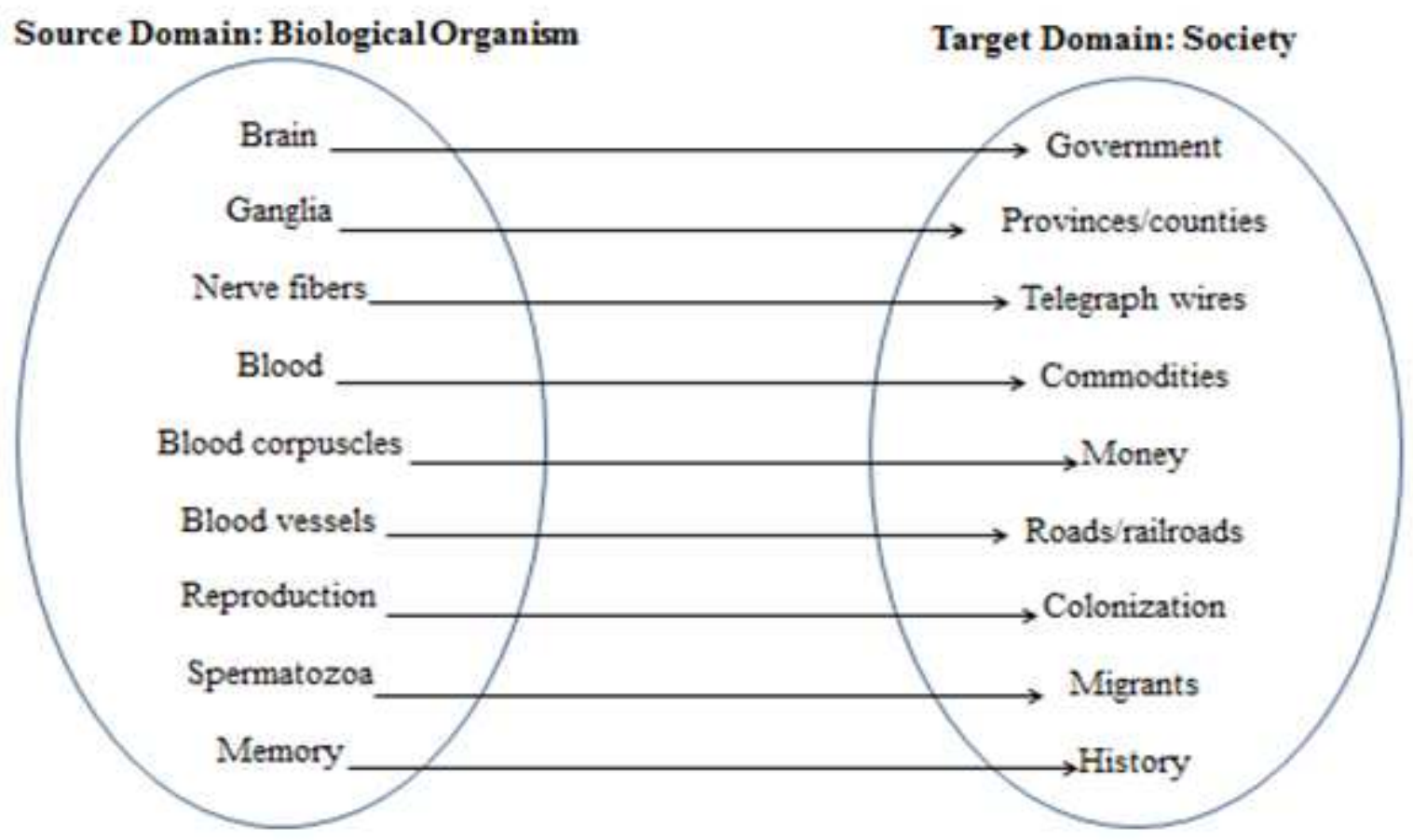

Figure 1: Some commonplace Nineteenth Century mappings of the generalized conceptual metaphor SOCIETY IS A BIOLOGICAL ORGANISM.

There are numerous problems with this type of visual presentation. First, this brief list of correspondences is far from exhaustive. As Franklin Giddings drily noted in a review of Rene Worms' Organisme et Société (1896), the latter managed to describe the anatomy, physiology, and pathologies of the social organism in such detail over the course of 412 pages that 'the student who rejects it can have the satisfaction of knowing that he does so only after he has thoroughly acquainted himself with it' (Giddings 1896: 348). In contrast, my visual representation merely supplies a very selective summary and should not be mistaken for a thorough tabulation.

Second, it does not capture the fact that many of the mappings were seen to hold only under carefully circumscribed conditions. For example, the social organism's nervous system was seen as something that emerged in the course of its evolution from simplicity to complexity. Just as simple organisms have no nervous system - so the argument went - simple societies have no counterpart to the nervous system (Spencer 1860/1996: 305-306). Hence, the nervous system/telegraph correspondence was deemed only to hold in cases involving comparisons between complex societies and complex organisms. My visual representation does not render visible these complications and caveats.

Third, it does not convey the various differences between members of the biological school. Many of the correspondences in the scheme I constructed were vehemently rejected by at least some members of the school: for example, there was no consensus that the government is the brain of the social organism. Indeed, the most influential member of the school denied that the social organism has any counterpart to the brain. (I will discuss this particular controversy in detail in a later section.) Similarly, while most members of the school agreed that the source domain slot for the cell had a 
counterpart in the target domain, they disagreed whether it was the individual, the couple, the family, or the clan. Commenting on these conflicting correspondences, Ward drily noted that it is somewhat surprising that no one seems to have thought of comparing men to sperm cells and women to germ cells. The married or propagating couple would then correspond to the fertilized ovum or blastosphere' (1902: 484). If one aims to show that mappings not merely changed over time, but were not fixed at a particular time either, then it would clearly be highly relevant to focus on such conflicts; I will do just that in a later section. In short, my attempt to visualize the metaphor represents a generalized set of mappings meant to convey the basic spirit of the broader school; but it does not capture important differences between individual thinkers. Despite this limitation, it arguably serves a useful purpose. While it does not capture well conflicting interpretations of the same metaphor within a specific period, it does convey which correspondences counted as candidates for consideration in that period. Even though Nineteenth Century sociologists disagreed whether the source domain slot for the cell had a counterpart in the target domain, the mapping was conceivable to every Nineteenth Century thinker. By contrast, most of their predecessors did not know anything about cells and thus could not search for conceptual counterparts at all. At any rate, it is absent from all earlier versions of the metaphor that I have come across. If there are earlier instances of cell mappings, it is unlikely that they emerged before the middle of the Seventeenth Century, given that Robert Hooke only discovered cells in the $1660 \mathrm{~s}$.

Hopefully the nature and significance of the issue will become clear as the argument proceeds. Before I pay further attention to it, however, allow me to spell out the most serious shortcoming of my visual presentation in more detail.

\section{STATIC SYSTEM OR DYNAMIC PROCESS?}

Pressed into a visual format shorn of all contextual details as I have done above, Ward's list may seem to conform very neatly to Lakoff's contention that metaphors should be seen as 'a fixed pattern of ontological correspondences across domains'. As soon as one begins to add contextual details, however, a different and more dynamic scenario begins to unfold. While some of the mappings on Ward's list have long pedigrees, ${ }^{7}$ many are decidedly historically situated: a number of them arguably could not have been made prior to the Nineteenth Century. To see that this was indeed the case requires that one takes seriously Michael Mann's dry observation (1986: 6) that 'the greatest contribution of the historian to the methodology of the social sciences is the date'.

\footnotetext{
${ }^{7}$ For example, the mapping between reproduction and colonization already appeared in Hobbes' Leviathan (2.24). In a section with the telling title 'Of the Nutrition, and Procreation of a Commonwealth', Hobbes (1909: 194) argued that 'The Procreation, or Children of a Commonwealth, are those we call Plantations, or Colonies'. The mapping between money and blood also has a long history (see Johnson 1966); but there are exceptions even to that rule: thus, Davanzati (1588) argued that money corresponds to blood, but noted that 'great and grave authors pretend that money is the nerve system of war and the republic'. The reader will have noticed that Ward's list also included a few alternative target-domain counterparts to blood.
} 
By focusing on when a particular mapping was made, one begins to observe the intellectual conditions that made it possible, one begins to grasp when the mapping could not have been made, and one begins to notice that the metaphor has something resembling a fossil record. Despite a few annoying gaps, that record contains telling traces of the tangled trajectory whereby a few stray remarks about the social organism, made by Plato, Aristotle, and Plutarch, was transformed into the sustained ruminations one encounters in Nineteenth Century sociology. Of course, once one has limited the scope of the investigation by specifying when a particular mapping was made, one also needs to specify who made it. As I will show in a later section, one often encounters significant differences between the sets of mappings postulated by two thinkers of the same school and era. While both avenues of inquiry are likely to lead to the conclusion that mappings are neither fixed nor static, they do so in logically distinct ways. I will initially focus exclusively on the first issue, and leave the second for later.

Consider the mapping between the nervous system and telegraph. That extension occurs in a number of texts from the middle of the Nineteenth Century onwards. The most influential version and, arguably, the most densely elaborated - can be found in Herbert Spencer's essay The social organism, which first appeared in The Westminster Review in January $1860 .^{8}$ Allow me to quote from it at length, to demonstrate what gets lost between the actual text and the neat ' $x \rightarrow y$ ' type of representation I used earlier (Spencer 1996: 305-306):

Thus far in comparing the governmental organization of the body-politic with that of an individual body, we have considered only the respective coordinating centres. We have yet to consider the channels through which these coordinating centres receive information and convey commands. In the simplest societies, as in the simplest organisms, there is no 'internuncial apparatus', as Hunter styled the nervous system. Consequently, impressions can be but slowly propagated from unit to unit throughout the whole mass. The same progress, however, which, in animal-organization, shows itself in the establishment of ganglia or directive centres, shows itself also in the establishment of nerve-threads, through which the ganglia receive and convey impressions and so control remote organs. And in societies the like eventually takes place. After a long period during which the directive centres communicate with various parts of the society through other means, there at last comes into existence an 'internuncial apparatus', analogous to that found in individual bodies. The comparison of telegraph-wires to nerves is familiar to all. It applies, however, to an extent not commonly supposed. Thus, throughout the vertebrate subkingdom, the great nerve-bundles diverge from the vertebrate axis side by side with the great arteries; and similarly, our groups of telegraph-wires are carried along the sides of our railways. The most striking parallelism, however, remains. Into each great bundle of nerves, as it leaves the axis of the body along with an artery, there enters a branch of the sympathetic nerve; which branch, accompanying the artery throughout its ramifications, has the function of regulating its diameter and otherwise controlling the flow of blood through it according to local requirements. Analogously, in the group of telegraph-wires running alongside each railway, there is a wire for the purpose of regulating the traffic - for retarding or expediting the flow of passengers and

\footnotetext{
${ }^{8}$ Spencer first presented his version of the social-organism metaphor in Social Statics (Spencer 1851: 390-391, 419, 448-456) - roughly a decade before the publication of Darwin's The Origin of Species (1859). More generally, as Nisbet notes (1975: 161), 'all of the principal works in the formation of the theory of social evolution had made their appearance before the publication of Darwin's book'. This might explain why the biological school's various versions of the metaphor contain almost no traces of Darwinism, and why it would be misleading to call them social Darwinists.
} 
commodities, as the local conditions demand. Probably, when our now rudimentary telegraphsystem is fully developed, other analogies will be traceable.

Just about every single item on Ward's list corresponds to a dense stretch of metaphorical reasoning like the above. This particular passage illustrates why it is somewhat misleading to say simply that Spencer made a mapping between the nervous system and the telegraph. After all, he notes that neither 'the simplest societies' nor 'the simplest organisms' have a nervous system. In Spencer's scheme of things, both societies and organisms evolve; and, in relatively advanced societies as in relatively complex organisms, a 'nervous system' gradually takes shape. Seen thus, the mapping between nerve fibres and telegraph wires is not made by aligning societies and organisms but by aligning specific types of societies and specific types of organisms. In both cases, the type is defined in terms of its place in an evolutionary sequence, in the course of which its characteristics constantly changed. ${ }^{9}$

That line of reasoning was as characteristic of Nineteenth Century sociologists as it was uncharacteristic of medieval philosophers. Consider how John of Salisbury construed the metaphor in his Policraticus, completed in 1159. Having re-introduced that ancient metaphor by means of the remark that 'a commonwealth, according to Plutarch, is a certain body', John proceeded to map the physiology of the body politic, proposing that clerics are the soul of the commonwealth, the prince the head, senators the heart, judges the senses, financiers the intestines, soldiers the one hand, tax collectors the other, artisans the one foot, peasants the other (Policraticus 5.2). Significantly, while everything in Spencer's scheme evolved, John of Salisbury portrayed a social order in which everyone had a fixed place and a permanent function. There are no indications that it occurred to him to see the commonwealth as the kind of thing that could evolve; medieval conceptions of the source domain probably would not have prompted him to consider the possibility.

Roughly seven centuries later, when Spencer observed the social organism, he did so from a perspective in which evolution affected the meanings of, and the relations between, just about all the slots in the source domain. ${ }^{10}$ Moreover, the social changes caused by the French Revolution and the Industrial Revolution undoubtedly yielded much more dynamic conceptions of the target domain, independent of the more dynamic conceptions of the source domain. As Eric Hobsbawm (1996: 1) reminds his readers in his aptly titled The Age of Revolution, the 'dual revolution' not merely

\footnotetext{
${ }^{9}$ Actually, Spencer's account involved a sleight of hand which created the illusion that he was demonstrating how societies evolved from simplicity to complexity. Spencer never offered examples of how a persisting entity changed over time. Rather, his evidence involved contemporary societies, which he arranged on a continuum stretching from 'the lowest races' (Spencer's favourite savages were the Bushmen of Southern Africa) to the 'most advanced' (say, the English), with a range of intermediate categories such as 'the aboriginals'. Spencer then created the illusion that his classificatory scheme represented a succession of differences over time whereas it actually involved differences between societies all existing at the same time. In later works like The Study of Sociology (1873), Spencer admitted (1873: 329) it had been an 'erroneous preconception' to hold that 'the different forms of society presented by savage and civilized races all over the globe... are but different stages in the evolution of one form'. See Nisbet (2002: 96-98, 1975: 195-208) for a more detailed discussion of these problems.

${ }^{10}$ Such rearrangements of the entire relational structure of a domain are well known from other fields. Thus, as Gentner and Wolff (2000: 317) note, 'the shift from Thompson's plum-pudding model to Rutherford's solar system model [of the atom] resulted in a fundamental rearrangement of already known elements'.
} 
necessitated the invention of concepts like 'capitalism' and 'working class', but also ones like 'scientist' and 'statistics'. In short, both domains were in rapid motion, and the mappings between them could hardly have failed to follow.

Unfortunately, John of Salisbury's version of the metaphor does not contain any reference to the nerves of the social organism, which means that we cannot compare his construal with Spencer's in that respect. Then again, Sherlock Holmes famously found a vital clue in a dog that failed to bark. Adopting a similar logic, Lovejoy reckoned (1941: 264-265) that the things a writer doesn't say 'may be even more noteworthy than the things he does say or the consequences he deduce[s]'. Such 'negative facts' have considerable value when one tries to understand the fact that the social organism metaphor did not include any mapping between nerves and telegraphs prior to the mid Nineteenth Century. The absence of any mapping involving nerves in John of Salisbury's version of the metaphor, for example, is arguably due to the fact that early medieval minds knew almost nothing about the nervous system.

Later, a number of John of Salisbury's successors did make reference to the social organism's nerves, which they projected onto various target domain candidates. Thus, Bernardo Davanzati's $A$ Discourse upon Coins (1588) contains a casual comment about 'great and grave authors' who held that 'money is the nerve system [sinews?] of war and the republic'. ${ }^{11}$ Davanzati disagreed, and argued that money should rather be likened to blood. Moreover, throughout the Seventeenth Century, one finds frequent reference to the 'nerves' of the body politic. This was probably due to the interest generated by Descartes' famous hydraulic theory of the nervous system, according to which the heart continually generates 'a very subtle fluid' (the so-called 'animal spirits') which then ascends to the brain 'as to a sort of reservoir' from where it is pumped through hollow nerves, thereby causing muscles to inflate or contract (Descartes, quoted in Hodgson, 1990: 418). A somewhat different conception of the nerves featured prominently in that strange beast - part organism, part machine, and part Biblical monster - that Hobbes (1909: 8) conjured in the opening pages of Leviathan. He started out by proposing a mechanistic conception of organisms ${ }^{12}$ : 'for what is the Heart, but a Spring; and the Nerves, but so many Strings; and the Joynts, but so many Wheeles, giving motion to the whole Body'. He then added that the state is 'but an Artificiall Man, though of greater stature and strength than the

\footnotetext{
${ }^{11}$ This is the translation provided by Jerah Johnson (1966: 120), which differs in subtle but significant respects from Toland's 1696 translation; the latter held that 'some grave and famous Authors have call'd Money the Sinews of War and Government'. I neither have a copy of the original Italian version nor the knowledge of Sixteenth Century Italian needed to decide which translation is more apt. It is worth noting, however, that the terms 'nerves' and 'sinews' were apparently used interchangeably by English speakers until the Seventeenth Century (Oxford English Dictionary). Seen thus, to ask which translation is better seems more important from a modern perspective than it probably would have seemed from an early modern perspective: our schema for the human body has distinct slots for sinews and nerves; theirs may well have had only one.

${ }^{12}$ A thorough analysis of Hobbes' account of the social organism would require that one pays careful attention to the ways he constantly blended machine and organic metaphors. The mechanistic dimensions of his world view may well explain some of the peculiarities of his construal of the social organism metaphor. However, it is beyond the scope of this essay to dig deeper into how his fondness for this type of mixed metaphor may have shaped the mappings he proposed.
} 
Naturall, for whose protection and defence it was intended'. A series of mappings between the state and the 'body natural' followed. Hobbes ventured that sovereignty is the soul of the state, the judiciary is the joints, wealth is strength, counsellors are memory, concord is health, sedition is sickness, civil war is death, and 'Reward and Punishment (by which fastned to the seate of the Sovereignty, every joynt and member is moved to performe his duty) are the Nerves, that do the same in the Body Naturall'. In Chapter XXIII, there is another reference to the nerves of the social organism, but this time, Hobbes (1909: 185) ventured that 'Publique Ministers resembleth the Nerves and Tendons that move the severall limbs of a body naturall'.

\begin{tabular}{|l|l|l|l|}
\hline Author & $\begin{array}{l}\text { Source domain } \\
\text { element }\end{array}$ & $\begin{array}{l}\text { Proposed target } \\
\text { domain counterpart }\end{array}$ & $\begin{array}{l}\text { Approximate } \\
\text { period }\end{array}$ \\
\hline Plato, Aristotle, etc & $\begin{array}{l}\text { No mention of } \\
\text { nerves }\end{array}$ & $?$ & $\begin{array}{l}\text { Classical } \\
\text { antiquity }\end{array}$ \\
\hline $\begin{array}{l}\text { Davanzativs } \\
\text { (unidentified) "great } \\
\text { and grave authors" }\end{array}$ & $\begin{array}{l}\text { Blood vs } \\
\text { nerves/sinews }\end{array}$ & Money & $16^{\text {th-century }}$ \\
\hline $\begin{array}{l}\text { Hobbes } \\
\text { Nerves }\end{array}$ & $\begin{array}{l}\text { Reward and } \\
\text { Punishment / Public } \\
\text { ministers }\end{array}$ & $17^{\text {th-century }}$ \\
\hline Spencer & Nerves & Telegraph & $19^{\text {th-century }}$ \\
\hline
\end{tabular}

Figure 2: One finds internal inconsistencies in the mappings proposed by a single author and those between authors from different periods.

To a later generation of thinkers, the mappings proposed by earlier writers often appeared to be a mystery. Consider Herbert Spencer's list of complaints about Hobbes' inconsistencies (1996: 270):

If the sovereignty is the soul of the body politic, how can it be that magistrates, who are a kind of deputy-sovereigns, should be comparable to joints? Or, again, how can the three mental functions, memory, reason, and will, be severally analogous, the first to counselors, who are a class of public officers, and the other two to equity and laws, which are not classes of officers, but abstractions? Or, once more, if magistrates are the artificial joints of society, how can reward and punishment be its nerves? Its nerves must surely be some class of persons.

Spencer's criticism is quite similar to the critique that Seventeenth Century scientists directed at the alchemist tradition (Gentner \& Jeziorski, 1993) regarding the lack of systematicity in the alchemists' proposed mappings. Indeed, Spencer's analysis of Hobbes' construal of the metaphor anticipates more than one claim made by proponents of Structure Mapping Theory: users of a metaphor typically must actively align two domains; those domains can be aligned differently; and different initial alignments yield different projections. While critical of Hobbes' perceived inconsistency, however, Spencer did not suggest that Hobbes should have made the same mappings that he (Spencer) considered the most 
cogent, probably because he realized that Hobbes could not have made a mapping between, say, the nervous system and the telegraph. As I have already noted, Spencer was quite aware that many of his mappings were historically situated and certainly not 'fixed correspondences' that could have occurred to anyone, anytime, anywhere (1996: 269, emphasis added):

A perception that there exists some analogy between the body politic and a living individual body, was early reached; and has from time to time re-appeared in literature. But this perception was necessarily vague and more or less fanciful. In the absence of physiological science, and especially of those comprehensive generalizations which it has but lately reached, it was impossible to discern the real parallelisms.

Spencer was surely onto something significant when he suggested that the rapid developments during the Nineteenth Century in scientific fields such as physiology had enabled him to make mappings between the two domains that could not have occurred to Hobbes or Plato - despite the fact that both of them used the social organism metaphor. To see why these mappings could not have been made earlier or elsewhere, consider Laura Otis' observation (2002: 105) that, 'in 1851, the telegraph and the nervous system appeared to be doing the same thing and for the same reasons. Their common purpose was the transmission of information, and they both conveyed this information as alterations in electrical signals'. This remark is interesting for at least three reasons. First, it suggests that the mapping was based on a similarity between the telegraph and nervous system: both transmit information by means of alterations in electrical signals; or rather - and this brings me to the second noteworthy feature of the observation - the telegraph and nervous system appeared to be similar in the relevant respects. Third, Otis writes that the telegraph and nervous system appeared similar around 1851 - which is to imply that they may not have appeared similar in, say, 1751. The third issue is the most interesting, but all three deserve closer attention. Let us take a look.

To say that the mapping between the telegraph and nervous system was motivated by similarity is to court controversy. Scepticism about similarity has resurfaced regularly ever since I.A. Richards remarked that, 'once we begin to examine attentively interactions which do not work through resemblances between tenor and vehicle, but depend upon other relations between them including disparities, some of our most prevalent, over-simple, ruling assumptions about metaphors as comparisons are soon exposed' (2001:72, Richards' emphasis). Richards' remark does not imply that similarity cannot serve as one of the grounds for metaphor. Indeed, he emphasized that one would 'perish quickly' without one's 'eye for resemblances'. Subsequent critics have not always circumscribed their criticisms as carefully.

Contemporary studies of cognition likewise harbour considerable scepticism towards similarity. Thus, while Lakoff and Johnson originally championed a perspective that focused on the creation of similarity (1980:147-155), Lakoff later suggested that 'metaphor is mostly based on correspondences in our experiences, rather than on similarity' (1993:245, emphasis added). ${ }^{13}$

\footnotetext{
${ }^{13}$ For an attempt to reconcile accounts that trace the motivation for different types of metaphor to 'experiential correlations' or 'resemblance', see (Grady 1999).
} 
Even so, accounts that give similarity a central role still have very able defenders (e.g., Gentner \& Jeziorski 1993, Gentner \& Wolff, 2000, Gentner et al. 2001). Such accounts fit neatly with Nineteenth Century sociologists' assumptions about why they made the mappings they did. In this regard, Spencer made an interesting statement in The Study of Sociology (1873: 330), which shows that not only similarity but also criticisms of similarity were subject to critical scrutiny in the Nineteenth Century:

Figures of speech, which often mislead by conveying the notion of complete likeness where only slight similarity exists, occasionally mislead by making an actual correspondence seem a fancy. A metaphor, when used to express a real resemblance, raises a suspicion of mere imaginary resemblance; and so obscures the perception of intrinsic kinship. It is thus with the phrases 'body politic', 'political organization', and others, which tacitly liken a society to a living creature: they are assumed to be phrases having a certain convenience but expressing no fact - tending rather to foster a fiction. And yet metaphors are here more than metaphors in the ordinary sense. They are devices of speech hit upon to suggest a truth at first dimly perceived, but which grows clearer the more carefully the evidence is examined. That there is a real analogy between an individual organism and a social organism, becomes undeniable when certain necessities determining structure are seen to govern them in common.

One may be sceptical about Spencer's statement that 'metaphors are here more than metaphors in the ordinary sense', but his basic point is worth pondering: it is no less erroneous to dismiss a real similarity as a fancy than to treat a fancy as a real similarity. At any rate, Otis' observation that both the telegraph and nervous system were seen to transmit information as alterations in electrical signals provides a candidate as plausible as any 'experiential correlation' I can think of. (In fact, I cannot think of one; but maybe I lack the imagination needed to conjure a plausible candidate.)

For present purposes, the most important issue lies in Otis' claim that 'in 1851, the telegraph and the nervous system appeared to be doing the same thing and for the same reasons' - implying that, before 1851, they would not necessarily have appeared relevantly similar. Indeed, it only requires a modicum of historical sensibility to see that the mapping could not have been made a mere century earlier. In 1760, the telegraph had not yet been invented: the first commercial telegraph was constructed and patented in the 1830s. Moreover, in 1760, 'animal electricity' awaited discovery: that notion only made its appearance on the intellectual circuit in 1791, when Galvani published De Viribus Electricitatis. ${ }^{14}$ Anyone who did not know about animal electricity could not have entertained the thought that nerves transmit information as alterations in electrical signals; such a person would not have thought that nerves appear similar to telegraphs, either.

Hence, if one could look into the mind of an educated European whose lifespan coincided roughly with that of, say, Marie Antoinette (1755-1793), one would find no 'fixed correspondence' between the nervous system and the telegraph. To an educated European born the day the Bastille fell and in his sixties by the time one tries to reconstruct the contents of his mind, however, the mapping may well have seemed quite natural. More generally, two domains that appear to differ in a particular respect at a particular time may appear similar in the same respect a few decades later. One could say

\footnotetext{
${ }^{14} \mathrm{I}$ am not suggesting that Galvani discovered the nervous system, but rather that his discovery of 'animal electricity' led to a radical re-conceptualization thereof. It was only under this new conception that it made sense to say that the nervous system resembled the telegraph.
} 
there was a 'fixed correspondence' between nerves and telegraph in a particular intellectual community, by the middle of the Nineteenth Century.

One may quibble about the exact date by which 'the telegraph and the nervous system appeared to be doing the same thing'. By 1851, the telegraph and nervous system may well have appeared 'to do the same thing' to a relatively small group of inventors like Samuel Morse, who tried to model the telegraph on the nervous system, and a few neurophysiologists like Emil DuBois-Reymond, who viewed the nervous system as a telegraph network of sorts. Thus, DuBois-Reymond (as quoted in Otis, 2002: 114-115) argued that:

[Just as] the central station of the electrical telegraph in the Post Office in Königsstrasse is in communication with the outmost borders of the monarchy through its gigantic web of copper wire, just so the soul in its office, the brain, endlessly receives dispatches from the outermost limits of its empire through its telegraph wires, the nerves, and sends out its orders in all directions to its civil servants, the muscles.

As an aside, this passage poses an interesting challenge to Lakoff and Turner's claim that 'we map one way only', and that - contrary to Max Black's interaction theory - it is not the case that our language 'go both ways' (1989: 131-132). ${ }^{15}$ Yet, as far as I can see, DuBois-Reymond's remark neatly reverses what would normally count as the source and target domain in sociological discourses - and neatly reverses specific mappings as well: telegraph wires are described as the nerve fibres of the social organism in the one case; nerve fibres are depicted as the telegraph wires of the human body in the other.

I digress. The point I wanted to make is simply that it is not clear exactly when 'the comparison of telegraph-wires to nerves [became] familiar to all', as Spencer put it. Note that, while Spencer had already made numerous, elaborate references to the social organism in his Social Statics (1851: 390$391 ; 419 ; 448-456)$, one finds no mention of a correspondence between the telegraph and nervous system in that work. In 1851 - after the telegraph had been invented, and after animal electricity had been discovered - the similarity between them was still not immediately obvious to everyone, after all.

One may disagree about how, exactly, an extension that was hardly conceivable in 1760 turned into an unexploited opportunity by 1800 , a novelty by mid-century, and a commonplace by 1860 . Surely though my brief reconstruction of the process indicates that, pace Lakoff, one is dealing with a process. One may add that it is an open-ended process. To see why, consider again the passage containing Spencer's musings on the correspondence between nerve fibres and telegraph wires specifically, his comment that, 'probably, when our now rudimentary telegraph-system is fully developed, other analogies will be traceable' (Spencer, 1996: 306).

That remark hints at an insight that probably seems so obvious, once it has been pointed out, that one may be tempted to dismiss it as too obvious to matter. Even so, it is important. The mapping between the telegraph and nervous system did not remain static, because telegraph systems were

\footnotetext{
${ }^{15} \mathrm{~A}$ few years later, Turner began to distance himself from the notion that metaphors involve unidirectional mappings (Turner \& Fauconnier 1995). He later proposed an elaborate alternative involving multi-directional projections between at least four mental spaces (Fauconnier \& Turner 2002).
} 
continuously altered and theories of the nervous system constantly advanced. This created ever more opportunities for novel extensions and new elaborations, provided that plausible counterparts could be identified in the opposing domain.

The nerve-telegraph mapping was by no means the only novel element in Spencer's construal of the metaphor. Consider his observation that earlier writers, such as Plato and Hobbes, simply assumed that 'the organization of a society is comparable, not simply to the organization of a living body in general, but to the organization of the human body in particular' (Spencer 1996: 271, emphasis added). While this might be the most obvious way to construe the metaphor, Spencer continued, it is certainly not the only way. Indeed, he claimed that that was the 'chief error' of earlier writers - 'one of those fancies which we commonly find mixed up with the truths of early speculation' (Spencer 1996: 271). Having rejected the claim that society is similar to a human organism, Spencer proceeded to reframe the metaphor by comparing different kinds of societies to different kinds of organisms. $\mathrm{He}$ aligned 'the lowest races, as the Bushmen' with 'the lowest animal and vegetal forms [such as] Protozoa and Protophyta'; he aligned the somewhat more complex 'aboriginal tribes' with somewhat more complex organisms such as Acrogens; he aligned 'civilized societies' with still more complex 'creatures like the Physalia' (Spencer 1996: 277-283). ${ }^{16}$ In constructing these comparisons, Spencer did a number of novel things.

First, while Spencer was not the first to suggest that societies evolve, his account of how simple societies evolve into more complex ones was novel. ${ }^{17}$ He borrowed his key ideas from 'the investigations of Wolff, Goethe, and Von Baer, [who] have established the truth that the series of changes gone through during the development of a seed into a tree, or an ovum into an animal, constitute an advance from homogeneity of structure to heterogeneity of structure' (Spencer 1891: 9). The first step in the evolutionary process, he continued, involves 'the appearance of a difference between two parts of [a substance that was initially uniform throughout] - or, as the phenomenon is called in physiological language, a differentiation' (1891: 10). Each of these 'differentiated divisions' begins to 'exhibit some contrast of parts'; it is by means of such continuously repeated differentiations, 'simultaneously going on in all parts of the embryo', that the embryo evolves into the mature organism (1891: 10). Spencer not only reckoned that this was 'the history of all organisms whatever': he went a step further and claimed that 'this law of organic progress is the law of all progress. Whether it be in the development of the Earth, in the development of Life upon its surface,

\footnotetext{
${ }^{16}$ Spencer's comparisons create interesting challenges for proponents of the idea that 'basic level categories' have a privileged position in cognition (Lakoff 1987). Spencer's arguments are littered with references to biological categories from just about all the taxonomic levels between domain, kingdom, and phylum on the one end of the spectrum, to family, genus, and species on the other. In the course of a single page (1996: 278), Spencer made reference to Protophyta, Diatomaceæ, Conferva, Monilia, Hydrodictyon, Ulva, Thallogens, Protozoa, Foraminifera, and Vorticelle. Throughout the text, references to such categories are employed metaphorically: 'in the evolution of a large society out of a cluster of small ones, there is a gradual obliteration of the original lines of separation - a change to which, also, we may see analogies in living bodies. The subkingdom Annulosa, furnishes good illustrations...' (Spencer 1996: 287, emphasis added).

${ }^{17}$ I discuss point in more detail elsewhere (Mouton 2009, 2012) and merely sketch the broad outlines of the argument here.
} 
in the development of Society, of Government, of Manufactures, of Commerce, of Language, Literature, Science, Art, this same evolution of the simple into the complex, through successive differentiations, holds throughout' (1891:10, emphasis added). In short, Spencer borrowed a novel theory of embryonic evolvement from the biology of his time, and then projected it onto much larger screens. Seen thus, when Wolf and Von Baer broke with Eighteenth Century embryologists' preformationism ${ }^{18}$ and proposed their epigenetic alternative, they unintentionally created opportunities for extending the social organism metaphor that Spencer was quick to notice and exploit.

Second, many of Spencer's comparisons involved microorganisms that were unknown until the middle of the Nineteenth Century. As Elwick notes, many of the organisms were not merely newly discovered but so strange that their 'very status as unitary individuals was questioned in the 1840s and '50s. Many of these invertebrate animals were seen as compound organisms, as aggregations of harmoniously-interacting parts. In these organisms, each part had a surprising amount of independence, often having its own simple "brain”, the ganglion' (Elwick 2003: 35). This opened up opportunities for reframing the social organism metaphor in novel ways. For example, Spencer observed that some of these simple organisms have no organs with specialized functions and can thus multiply 'by the spontaneous division of their bodies, [and thereby] produce halves which may either become quite separate and move away in different directions, or may continue attached' (Spencer 1996: 278). In primitive societies without division of labour, he suggested, one often finds an analogous process: since the members are not bound together by the form of interdependence created by specialization, groups continuously multiply by dividing the social body. In contrast, if one thinks of society as a human body, then such a scenario is difficult to conceptualize and indeed unpleasant to contemplate. I will discuss other ways Spencer exploited his knowledge of these newly discovered organisms in the next section. Suffice it for now to say that, in the cases described, one is not dealing with previously unused parts of a static mapping pattern that had always been around and that Spencer merely had to activate. Until the early Nineteenth Century, the relevant parts of the source domain were not unused but unknown.

\section{MAPPINGS WERE NEITHER FIXED OVER TIME, NOR AT A PARTICULAR TIME}

Thus far, I have tried to demonstrate that mappings change over time; but I have not addressed the possibility that they may be fixed at a particular point in time: that is, they might well look fixed if one could take a snapshot of a particular slice of the metaphor's history. However, this, too, is misleading. As far as the case of the social organism is concerned, recurrent controversy seems to have been the norm and few mappings remained uncontested for long.

Consider again the biological school of Nineteenth Century sociology. Given the traditional tendency, in organicist thought, to emphasize social harmony, it is not surprising that members of the

\footnotetext{
${ }^{18}$ Basically, the preformationists believed that the complete organism is already pre-formed in the sperm and merely grows in size (Mandelbaum 1957: 358).
} 
school tended to downplay all signs of internal conflict as mere verbal disputes. Yet their attempts to paint a picture of broad consensus could not quite hide all the conflicts about which source domain entities were supposed to map onto which target domain entities. Take the tensions surrounding the idea that government is the brain of the social organism. This controversy lasted surprisingly long, got quite heated, and caught the attention of a broader public. One faction, including Lilienfeld and Worms, advocated the mapping more or less without qualification and viewed government as 'the chief coordinating and directing organ of society' (Barnes 1921: 492). The claim was typically followed by the normative enjoinder that 'the more highly developed the civilization of a society, the greater the desirable scope of state interference' (Barnes 1921: 492). A second group, perhaps comprising 'the majority of organicists', subscribed to the mapping 'with qualifications' (Ward 1902: 486) - the main qualification pertaining to the desirable scope of state interference. A third faction insisted that the brain corresponded to something else than the state. Thus, Jacques Novicow argued that the societal counterpart of the brain is the intellectual aristocracy, not the state (Barnes 1921: 492). A fourth group, led by Herbert Spencer, eventually came to the conclusion that society has no counterpart to the brain (Barnes 1921: 492, Ward 1902: 488-491).

The route that led to Spencer's rejection of the mapping is interesting. He rejected it primarily because of his prior ideological persuasions. Spencer realized that, if government were seen as the brain of society, the mapping could be used to justify ideas inconsistent with his commitment to libertarianism and laissez-faire capitalism. Instead of revising his ideology, he rejected the correspondence: 'It is well that the lives of all parts of an animal should be merged in the life of the whole, because the whole has a corporate consciousness capable of happiness or misery. But it is not so with a society; since its living units do not and cannot lose individual consciousness, and since the community as a whole has no corporate consciousness' (Spencer 1891: 276). There is something to be said for Eubanks' efforts to turn Lakoff's (1996) conception of the role of metaphor in shaping ideology on its head. Eubanks insists that, sometimes, it is the ideology that shapes the metaphor - or, more generally, that metaphoric mappings often turn out to be 'subordinate to the [culturally and historically situated] speakers' political, philosophical, social, and individual commitments' (Eubanks 1999: 419).

Even more interesting is the strategy Spencer employed to exclude the correspondence from consideration. He did not simply deny the mapping, but rather took an indirect approach that relied on presuppositions built into the very way he initially introduced the metaphor. As I already noted, he singled out the idea that society is comparable to the human body as the 'chief error' of earlier writers like Plato and Hobbes, and then proceeded to compare different types of societies to different types of organisms. I further noted how this enabled him to make a number of novel mappings. His alternative construal also served another purpose, however: it immediately ruled out a whole range of sourcedomain inference patterns that were obvious candidates for metaphorical projection under the traditional construal. If societies are compared to such simple forms of life as protozoa, which do not 
have brains, there is no point in asking what the societal counterpart of the brain is - and that was exactly one question Spencer wanted to keep off the agenda.

Not all of Spencer's successors agreed with his construal. However, it was no longer possible simply to take for granted that the social organism resembled a complex biological entity such as a human being. The idea still had its defenders, but now they actually had to defend it.

The controversy over whether the social organism had a brain was not the only contested mapping. As I mentioned earlier, Lester Ward's comparison of the correspondences conjured by Comte, Spencer, Lilienfeld, Worms, and Schäffle led him to conclude that the societal counterpart of the biological cell was apparently either the individual or the reproductive couple or the nuclear family or the clan (Ward 1902: 484). Mappings that appear neatly arranged into fixed patterns when one focuses on a given individual's construal of the metaphor turn out to be messy when one compares the construals of competing individuals. In short, metaphorical mappings rarely settle down into static systems.

This is potentially quite significant for understanding why the metaphor was pushed to such extremes by members of the biological school. It should not be necessary to cite much additional evidence to show that the metaphor was indeed pushed to extremes. Ward was decidedly not the only observer impressed by how far members of the school had managed to extend the metaphor. As Coker drily concluded (1910: 194), 'some found in the State even such organs as stomach, navel, or nose'. Similarly, Gerschenkron (1974: 435) commented that, given the 'rather extravagant' lengths to which Lilienfeld pushed the metaphor, it is "curious that Worms, despite his great admiration for Lilienfeld, felt that the latter had not gone far enough and in particular had failed to discover in society the counterpart of muscles, bones, and tendons in the human body'.

To see why the school pushed the metaphor to such extremes, one needs to shift one's focus. The relevant individuals did not merely form a school, but one identified primarily by its reliance on biological metaphors. To see why that mattered, in turn, one needs to look at the issue from a sociological rather than a cognitive or historical angle.

As Randall Collins convincingly demonstrates in his erudite account of the sociology of intellectual change, the history of thought is, to considerable extent, the history of 'groups of friends, discussion partners, close-knit circles that often have the characteristics of social movements' (Collins 1998: 3). Within such groups, one finds a limited attention space and an opportunity structure with only so many options. Rivalries inevitably arise when individuals in the group compete for limited attention. It is the desire to stay in the centre of attention that fills them with the energy needed to push an idea as far as it can go - preferably in a different direction from anyone else.

This could explain the extremes to which the social organism metaphor was pushed whenever groups like the biological school of Nineteenth Century sociology adopted it as a root metaphor. To see how, it is necessary to first correct my earlier reference to such 'largely forgotten figures' as Paul Lilienfeld, Auguste Schäffle, and Rene Worms. That these men are largely forgotten now does not 
mean that they were not important then: 'in their time, these writers were serious contenders in a struggle to develop knowledge about society and not self-evidently inferior to their opponents' (Barberis 2003: 54). ${ }^{19}$

Their 'struggle to develop knowledge about society' was a struggle to push the organism metaphor, by means of which they conceptualized society, further than - or in different directions from - their competitors. Either they could make a constructive contribution to its development by extending the metaphor in directions that competitors had overlooked, or they could make a critical contribution by questioning the validity of the mappings others had made.

Given this, Barberis overlooks something important when she notes that these individuals recognized each other as 'holders of a common theory of society... despite differences as to details' (Barberis, 2003: 54, emphasis added). It would be more informative to say that they recognized each other as holders of a common theory and therefore competed continuously to come up with variations to gain the attention and earn the respect of other members of the group. It was because they recognized each other as 'holders of a common theory of society' that there was a discussion at all, but it was the cultivation of 'differences as to details' that kept that discussion alive.

This line of thought draws attention to a number of facts of intellectual life that are too often disregarded or downplayed. First, reasoning is not simply 'the activation of certain neuronal groups in the brain given prior activation of other neuronal groups' (Lakoff 2006: 1). Its natural habitat is not limited to the inside of an individual's head; it is also a public activity. Second, the public life of any important metaphor is rarely peaceful; on the contrary, its development is largely driven by conflict and competition. Third, as a result it is highly unlikely that one will ever find a 'fixed and static system' of metaphors in any intellectual community, unless that community is moribund. Finally, it is worth emphasizing once more that mappings vary not just by time but also by thinker.

Hopefully, my casual sketch of the shape that the notion of a social organism assumed in Nineteenth Century sociology, and the brief contrasts I offered with what the metaphor looked like in earlier stages of its development, have served to convey more concretely what I have in mind when I suggest that the metaphor evolved, as well as what I mean when I contend that its various manifestations were historically situated and why I insist that Ward's list of mappings does not portray a permanent state in a static system but rather a temporary station in a dynamic process.

\section{FROM FIXED BODIES TO FIXED MAPPINGS}

This raises another question: if mappings are not as fixed or as static as Lakoff suggests, why is the belief that they are static seemingly so fixed in his thought? I can think of a number of possible explanations, the most plausible of which is that his fixation stems from some version of the broad

\footnotetext{
${ }^{19}$ Rene Worms (1869-1926) founded and edited the Revue Internationale de Sociologie, established the Société de Sociologie de Paris, and got himself elected to numerous learned societies. Albert Schäffle's (1831-1903) career included stints as chair of political economy at Tübingen, professor of political science in Vienna, and minister of commerce in the short-lived cabinet of Count Karl Sigmund von Hohenwart.
} 
claim that metaphors 'arise from the nature of our brains, bodies, and bodily experience' (Lakoff \& Johnson 1999: 5). Consider the following passage in which Lakoff discusses a conceptual metaphor he calls 'anger is the heat of a fluid in a container' (Lakoff 1987:383). He does so to illustrate how metaphors for feelings like anger are embodied (1987: 407, emphasis added):

Although the folk theory is only a folk theory, it has stood the test of time. It has made sense to hundreds of millions of English speakers over a period of roughly a thousand years. The Ekman group's results suggest that ordinary speakers of English by the millions have had a very subtle insight into their own physiology. Those results suggest that our concept of anger is embodied via the autonomic nervous system and that the conceptual metaphors and metonymies used in understanding anger are by no means arbitrary: instead they are motivated by our physiology.

This passage displays the logic that leads from certain versions of the notion of embodiment to the conclusion that mappings are fixed. The metaphor is presented as fixed: it has purportedly been around, in the same form, for 'roughly a thousand years'. Moreover, it is purportedly fixed because it is 'motivated by our physiology': the tacit premise being that 'our physiology' is surely quite fixed.

The passage also displays the problems with this line of thought. It conflates two distinct ideas and draw conclusions that only follow from the least plausible of them. ${ }^{20}$ To wit, Lakoff begins by talking about ordinary people's insights into their own physiology; but, halfway through the passage, he suddenly switches to talk about 'our physiology', as if there were no difference.

Surely there is an enormous difference. While human bodies are presumably much the same in modern America as they were in ancient Athens, "insights into" human bodies have changed radically. Aristotle deemed the heart to be the locus of thinking and declared that the brain primarily serves to cool down the blood. ${ }^{21}$ The sixteenth Century surgeon John Halle - who turned the body politic metaphor around to portray the body as a political system - declared 'the lyver' to be one of 'the chiefe governours', deriving this mapping from the Galenic principle that the liver constantly generates new blood from digested food, sending it on to the heart and the rest of the body (as quoted in Cohen 1994: 192). Medieval thinkers like Nicholas Oresme worried that (1956: 43-44) 'the body is disordered when the Humours flow too freely into one member of it, so that that member is often thus inflamed and overgrown while the others are whithered and shrunken and the body's due proportions are destroyed and its life shortened'.

Such examples illustrate two things. First, while Lakoff and some of his followers tend to speak as if everyone shares the same schemas for things like plants or bodies (see e.g. Lakoff \& Turner 1989: 61-62, 106), it seems to me that, throughout history, people have used very different schemas for inter alia the body: later schemas often contain slots that do not feature in earlier schemas at all and vice versa. Even when slots do overlap, they typically are filled with different content in different eras even as the relations between slots constantly changes.

\footnotetext{
${ }^{20}$ For a detailed discussion of other objections, see (Gevaert 2005).

${ }^{21}$ See e.g. Parts of Animals, 652b26. Crivellato and Ribatti (2006) provide a brief but useful overview of Aristotle's conception of the body.
} 
Second, such examples illustrate that ordinary phenomenological experience tells desperately little about what is going on inside one's own body and cannot answer questions as simple as 'where in the body does thinking take place?' or 'what is the function of the heart?' If it could, it would never have occurred to Aristotle to suggest that the heart is the seat of thinking. As Violi (2007: 54-55) puts it:

The body is not a self-evident concept, but the result of the various discourses that construct it. If the phenomenological experience of the body can appear an immediate one, the concept of 'body' certainly does not. Rather, it appears to be seen in terms of the construals made of it within any given disciplinary perspective.... The body as described by neurosciences is not the same body as the one described by psychoanalysis, or by experimental psychology, and so on. All these different 'bodies' are not reducible to one another.... Even the body as studied in medicine is a construal, so much so that different medical practices in different cultures construe as many different bodies as there are cultures: the 'Western' body studied in our medical tradition is not the same as the body mapped by Chinese acupuncture.

One may add that particular disciplines within 'our medical tradition' - say, anatomy or physiology have construed the body very differently over time. One cannot use premises that involve insights into one's own physiology to draw conclusions about how one's physiology motivates metaphors, or vice versa. One is dealing with radically different theories, with radically different consequences for understanding of metaphor. If metaphors are motivated by human physiology, they are likely to be fixed, since human physiology is relatively fixed. If, instead, they are motivated by insights into one's own physiology, they are bound to be fluid, since, over time, such insights have turned out to be occasionally factual, often false, and constantly changing.

I am not claiming that all notions of embodiment result in the belief that mappings are fixed. Indeed, in one of the earliest formulations of the idea, Lakoff and Johnson wrote (1980:57) that "what we call 'direct physical experience' is never merely a matter of having a body of a certain sort; rather, every experience takes place within a vast background of cultural presuppositions'. Such a perspective is much more likely to draw attention to the fluidity of mappings. Similarly, more recent attempts to understand the 'dual grounding' of metaphor (e.g., Sinha 1999) would be much easier to reconcile with the claim that metaphors evolve, in the sense I have described.

On the other hand, it seems to me that culture - and with it, variation - has become increasingly marginalized in Lakoff's thought over the years. In his latest writings, it appears as an afterthought at best. Indeed, in the most recent versions of the theory, there has been an almost exclusive emphasis on the neural underpinnings of metaphor, and a corresponding decrease in the significance attributed to cultural factors. Thus, Lakoff $(2006,2008)$ refers to his latest conjectures as 'The Neural Theory of Metaphor', and culture does not feature on his list of results from earlier versions of the theory that 'have stood the test of time' (Lakoff 2006: 10-11). Not surprisingly, references to 'fixed patterns' are common in these texts: the exclusive emphasis on brains, at the expense of the cultures in which they are embedded, leads to a focus on what is universal and fixed, rather than on what is local and fluid. 


\section{STATIC NOVELTY}

Another plausible explanation for why Lakoff mistakenly deems mappings to be fixed and static derives from the assumptions underlying his account of novel metaphor. "The problem with all the older research on novel metaphor', Lakoff suggests (1993: 237, emphasis added), 'is that it completely missed the major contribution played by the conventional system [in the production of novel metaphorical uses of language]'. This is not quite true. Back in 1959, Chaim Perelman and Lucie Olbrechts-Tyteca discussed traditional conceptions of the interplay between 'dormant' metaphors and novel extensions of those metaphors. They defined dormant metaphors as 'a stock of analogical material that gains ready acceptance because it is not merely known, but is integrated by language into the cultural tradition', and then delineated diverse techniques that the rhetorician could use to 'develop a fresh analogy, with the [dormant] metaphor as its starting point' (Perelman \& Olbrechts-Tyteca, 1959/2000: 405). They certainly did not completely miss the contribution of conventional metaphor in the production of novel extensions and elaborations.

Moreover, it seems to me that there are problems with Lakoff's account of novel metaphor: as I noted earlier, it seems curiously static. Lakoff and Johnson addressed the relation between conventional and novel metaphor already in Metaphors We Live By, where they argued that 'the metaphor THEORIES ARE BUILDINGS has a "used" part (foundation and outer shell) and an “unused" part (rooms, staircases, etc)' (Lakoff \& Johnson, 1980: 52-53). From this perspective, novel linguistic expressions such as 'he prefers massive Gothic theories covered with gargoyles' simply 'reflect the "unused" part of the metaphor' (1980: 52-53). The same idea recurs in Lakoff's later remarks about the relation between novel and conventional mappings (1993: 210-211, emphasis added):

Lexical items that are conventional in the source domain are not always conventional in the target domain. Instead, each source domain lexical item may or may not make use of the static mapping pattern. If it does, it has an extended lexicalized sense in the target domain, where that sense is characterized by the mapping. If not, the source domain lexical item will not have a conventional sense in the target domain, but may still be actively mapped in the case of novel metaphor.

To say that coining a novel extension amounts to using the normally 'unused' part of a metaphor implies that it has been there all along. This is plausible enough in some instances, but surely not in all. Consider again Ward's contention that the members of the biological school had pursued the social organism metaphor 'to its utmost limits' (Ward 1902: 480). As I hinted before, it would have been more correct to say that they pursued the metaphor as far as it could go in the late Nineteenth Century. Many of the mappings that occur regularly in the writings of their Twentieth Century counterparts, such as the idea that 'the analogue to a regulator gene in organizations is a higher-order coordinating routine' (Hannan \& Freeman 1986: 57), are conspicuously absent in Nineteenth Century discussions of the metaphor. Yet surely it does not make sense to say that 'regulator gene' was an 'unused' part of the metaphor back then. After all, Nineteenth Century sociologists lived in a world in which De Vries 
and Correns had not yet rediscovered Mendel's seminal experiments. They knew nothing about genes in general or regulator genes in particular. They could not exploit this 'unused' part of the metaphor because it was not part of the source domain at all.

Discoveries in various branches of biology have constantly generated opportunities to extend the social organism metaphor in new directions, by exploiting novel knowledge that was not earlier available. Such extensions could not have formed part of a pre-existing, static mapping pattern because the entities that would later be seen as corresponding to each other either had not been discovered yet or were conceptualized in very different ways. It makes no sense - even with the dubious benefit of anachronistic hindsight - to say something was 'unused' when it did not yet exist.

Seen thus, Lakoff's account of how novel mappings are generated begs the question of how the trick is done. It presupposes that a static mapping pattern was always already in place, when the very puzzle is how such patterns emerge in the first place. Seen thus, Lakoff's account exemplifies a problematic tendency among theorists of metaphor 'to read back onto the beginning of the process what can emerge only at the end' (Schön 1963: 59). Since Lakoff insists that metaphors should not be thought of as processes but as static and fixed sets of mappings, it is not surprising that he overlooks the problem.

\section{CONCLUDING REMARKS}

One could argue that Lakoff's conception of unused slots in static mapping patterns that are always already in place could only appear plausible from a perspective that is neither synchronic nor diachronic, but simply 'achronic'. Sewell (1997) offers a useful discussion of these three modes of thought and how they relate to historical explanations - or the absence thereof. When one says that an explanation is 'historical', Sewell (1997:40) argues, it could mean that the account involves happenings that take place over time; the focus is on process, sequence, flow. This is the diachronic face of history, which Sewell labels 'history as transformation'. On the other hand, it could also mean that the account tries to capture 'the distinct character and atmosphere of what we might call a block of time', where this particular 'block' happens to stand at a considerable distance from the one currently occupied (Sewell 1997: 41). This is the synchronic face of history, which Sewell calls 'history as temporal context'. As for 'achronic' thought - a mode of thinking that is 'without time' - it is rarely encountered in historiography, but seems fairly common outside. So in anthropology, Eric Wolf worries (1997: 95) that 'we have tended to conceptualize societies as if they existed in a timeless ethnographic present and in isolation from one another'; and one can still find ethnographic monographs in which 'the anthropologist posits a place where the natives... are somehow out of time and history' (Cohn 1980: 199). When anthropologists look at languages from this perspective, the result is typically pictures of a 'static linguistic system carried by a faceless and passive collectivity' 
(Wolf 1997: 16). It seems to me that the same thing happens in many of Lakoff's texts. ${ }^{22}$ Lakoff's $^{\prime}$ conception of static mapping patterns arguably stems from a mindset where time plays no role; it reminds one of 'one of those medieval paintings in which the far-flung scenes of a saint's life and martyrdom are depicted in a single continuous landscape' (Sewell 1997: 40). Applied to the case of the social organism, Lakoff's account would only make sense on the assumption that all knowledge about the source and target domains is always already available in a single continuous moment - an eternal present, so to speak - where all potential users of the metaphor can 'activate' whichever 'unused' parts of the static mapping pattern they may need.

What should be done? One could make a good start by inverting Lakoff's construal of the relation between conventional and novel metaphor. Whereas Lakoff (1993: 237) holds that older research 'completely missed the major contribution played by the conventional system [in the production of novel metaphorical uses of language]' (Lakoff, 1993:237), one could argue that Lakoff largely missed the major contribution played by novel metaphorical projections in the production of what becomes for short periods of time - 'the conventional system'. From this inverted perspective, what might first have appeared to be a set of fixed correspondences in a static system, the unused parts of which are occasionally activated to yield unusual extensions, is better seen as a series of fluid mappings embedded in a dynamic process that continuously generates genuinely novel opportunities to extend the metaphor. Novelty being a fleeting state, those extensions and elaborations either disappear or they become part of the conventional repertoire of a period - itself a temporary station, not a permanent state.

\section{REFERENCES}

Aristotle (1923). Politics, B. Jowett (tr.). Oxford: Clarendon Press.

Aristotle (1984). The Complete Works of Aristotle: The Revised Oxford Translation, J. Barnes (ed.). Princeton University Press.

Barberis, D.S. (2003). In search of an object: Organicist sociology and the reality of society in Fin-De-

Siècle France. History of the Human Sciences, 16(3): 51-72.

Barnes, H.E. (1921). Some contributions of sociology to modern political theory. The American Political Science Review, 15(4): 487-533.

Barron, D.N., West, E. \& Hannan, M.T. (1994). A time to grow and a time to die: Growth and mortality of credit unions in New York City, 1914-1990. The American Journal of Sociology, 100(2): 381-421.

Campbell, N.R. (1920). Physics: The Elements. Cambridge, UK: Cambridge University Press.

\footnotetext{
${ }^{22}$ Needless to say, this does not apply to all cognitive linguists; Brigitte Nerlich and Andreas Musolff are obvious exceptions to the rule. So is Tim Rohrer, who recently criticized the dogmatic tendency to 'consider embodiment as if it were something static or fixed, when in fact it is temporally dynamic in ontogenetic, historical, and phylogenetic terms' (2006: 119).
} 
Cohen, I.B. (1994). Harrington and Harvey: A theory of the state based on the new physiology. Journal of the History of Ideas, 55(2): 187.

Cohen, M.R. (1923). On the Logic of Fiction. The Journal of Philosophy, 20(18): 477-488.

Cohn, B.S. (1980). History and anthropology: The state of play. Comparative Studies in Society and History, 22(2): 198-221.

Coker, F.W. (1910). Organismic Theories of the State: Nineteenth Century Interpretations of the State as Organism or as Person. New York: Longmans, Green \& Co.

Collins, R. (1998). The Sociology of Philosophies: A Global Theory of Intellectual Change. Cambridge, MA, USA: Harvard University Press.

Crivellato, E. \& Ribatti, D. (2006). A portrait of Aristotle as an anatomist. Clinical Anatomy, 20(5): 447-485.

Davanzati, B. (1696 [1588]). A Discourse Upon Coins, Toland, J. (tr.). London. Available at: http://avalon.law.yale.edu/16th Century/coins.asp.

Davidson, D. (1978). What metaphors mean. Critical Inquiry, 5(1): 31-47. Reprinted in Sacks, S. (ed.) (1979). On Metaphor. Chicago: University of Chicago Press.

Durkheim, E. (1997 [1893]). The Division of Labour in Society. Free Press.

Elwick, J. (2003). Herbert Spencer and the disunity of the social organism. History of Science, 41(3572).

Eubanks, P. (1999). The story of conceptual metaphor: What motivates metaphoric mappings? Poetics Today, 20(3): 419-442.

Fauconnier, G. \& Turner, M. (2002). The Way We Think: Conceptual Blending and the Mind's Hidden Complexities. New York: Basic Books.

Fogelin, R. (1994). Metaphors, similes, and similarity. In Hintikka, J. (ed.), Aspects of Metaphor. Dordrecht: Kluwer Academic.

Freeman, J., Carroll, G.R. \& Hannan, M.T. (1983). The liability of newness: Age dependence in organizational death rates. American Sociological Review, 48(5): 692-710.

Frank, R.M. (2007). The language-organism-species analogy: A complex adaptive systems approach to shifting perspectives on 'language'. In Frank, R.M., Dirven, R., Ziemke, T. \& Bernardez, E. (eds.), Body, Language, and Mind. Volume 2: Sociocultural Situatedness. Mouton de Gruyter.

Gentner, D., Bowdle, B., Wolff, P. \& Boronat, C. (2001). Metaphor Is Like Analogy. In Gentner, D., Holyoak, K.J. \& Kokinov, B.N. (eds.), The Analogical Mind: Perspectives from Cognitive Science (199-253). Cambridge MA, USA: MIT Press.

Gentner, D. \& Jeziorski, M. (1993). The shift from metaphor to analogy in Western science. In Ortony, A. (ed.), Metaphor and Thought. Cambridge, UK: Cambridge University Press.

Gentner, D. \& Wolff, P. (2000). Metaphor and knowledge change. In Districh, E. \& Marbnau, A. (eds.), Cognitive Dynamics: Conceptual Change in Humans and Machines. Mahwah, NJ, USA: Lawrence Erlbaum Associates. 
Gerschenkron, A. (1974). Figures of speech in social sciences. Proceedings of the American Philosophical Society, 118(5): 431-448.

Gevaert, C. (2005). The anger Is heat question: Detecting cultural influence on the conceptualization of anger through diachronic corpus analysis. In Delbecque, N., Auwera, J. \& Geeraerts, D. (eds.), Perspectives on Variation: Sociolinguistic, Historical, Comparative. Mouton de Gruyter.

Giddings, F.H. (1896). Untitled review of Rene Worms et al. Political Science Quarterly 11(2): 346352.

Grady, J. (1999). A typology of motivation for conceptual metaphor: Correlation vs. resemblance. In Gibbs, R.W. and Steen, G.J. (eds.), Metaphor in Cognitive Linguistics. John Benjamins Publishing Company.

Hacking, I. (2002). Historical Ontology. Cambridge, MA, USA: Harvard University Press.

Hale, D.G. (1971). Coriolanus: The death of a political metaphor. Shakespeare Quarterly, 22(3): $197-$ 202.

Hale, D.G. (1973). The Body Politic: A Political Metaphor in Renaissance English Literature. The Hague: Mouton \& Co.

Hannan, M.T. \& Freeman, J. (1986). Where do organizational forms come from? Sociological Forum, 1(1): 50-72.

Harrington, J. (1737 [1656]). The Oceana, and Other Works. Collected, Methodiz'd, and Review'd by John Tolland. $3 d$ Edition. London. ${ }^{23}$

Hesse, M.B. (1966). Models and Analogies in Science. Notre Dame: University of Notre Dame Press.

Hobbes, T. (1651/1909). Leviathan. Oxford: Clarendon Press. ${ }^{24}$

Hobsbawm, E. (1996). The Age of Revolution, 1789-1848. New York: Vintage Books.

Hodgson, E.S. (1990). Long-range perspectives on neurobiology and behavior. American Zoologist 30(3): 403-505.

Howe, J. (2008). Argument is argument: An essay on conceptual metaphor and verbal dispute. Metaphor and Symbol, 23(1): 1-23.

Huxley, T.H. (1871). Administrative nihilism. In Huxley, T.H. (1873) Critiques and Addresses, London: Macmillan. ${ }^{25}$

Johnson, J. (1966). The money=blood metaphor, 1300-1800. Journal of Finance, 21(1): 119-122.

Johnson, M. \& Fernandez-Duque, D. (2002). Cause and effect theories of attention: The role of conceptual metaphors. General Review of Psychology, 6(2): 153-165.

Kövecses, Z. (2006). Language, Mind, and Culture: A Practical Introduction. Oxford: Oxford University Press.

Kövecses, Z. (2008). Conceptual metaphor theory: Some criticisms and alternative proposals. Annual Review of Cognitive Linguistics, 6: 168-184.

\footnotetext{
${ }^{23}$ Facsimile: http://archive.org/stream/oceanaotherworks00harr\#page/n5/mode/2up.

${ }^{24}$ Facsimile: http://archive.org/stream/hobbessleviathan00hobbuoft\#page/n35/mode/2up.

${ }^{25}$ Facsimile: http://archive.org/stream/critaddresses00huxlrich\#page/n21/mode/2up.
} 
Lakoff, G. (1987). Women, Fire, and Dangerous Things: What Categories Reveal About the Mind. Chicago: The University of Chicago Press.

Lakoff, G. (1993). The contemporary theory of metaphor. In Ortony, A. (ed.). Metaphor and Thought, Cambridge, UK: Cambridge University Press.

Lakoff, G. (1996). Moral Politics: What Conservatives Know That Liberals Don't. Chicago: University of Chicago Press.

Lakoff, G. (2006). The neural theory of metaphor. (Unpublished paper distributed on the electronic discussion forum of the International Cognitive Linguistics Association.)

Lakoff, G. (2008). The neural theory of metaphor. In Gibbs, R.W. (ed.), The Cambridge Handbook of Metaphor and Thought, Cambridge, UK: Cambridge University Press.

Lakoff, G. \& Johnson, M. (1980). Metaphors We Live By. Chicago: University of Chicago Press.

Lakoff, G. \& Johnson, M. (1999). Philosophy in the Flesh. New York: Basic Books.

Lakoff, G. \& Turner, M. (1989). More Than Cool Reason: A Field Guide to Poetic Metaphor. Chicago: University of Chicago Press.

Landau, M. (1972). Political Theory and Political Science: Studies in the Methodology of Political Inquiry. Macmillan.

Lovejoy, A.O. (1941). The meaning of romanticism for the historian of ideas. Journal of the History of Ideas, 2(3): 257-278.

Lovejoy, A.O. (1948). The Great Chain of Being: A Study of the History of an Idea. Cambridge, MA, USA. Harvard University Press.

Lovejoy, A.O. (1948b). Essays in the History of Ideas. The Johns Hopkins Press.

Mandelbaum, M. (1957). The scientific background of evolutionary theory in biology. Journal of the History of Ideas, 18(3): 342-361.

Mandelbaum, M. (1965). The history of ideas, intellectual history, and the history of philosophy. History and Theory, 5: 33-66.

Mandelbaum, M. (1971). History, Man and Reason. The Johns Hopkins Press.

Mann, M. (1988). European development: Approaching a historical explanation. In Baechler, J. (ed.). Europe and the Rise of Capitalism. Oxford, UK: Basil Blackwell.

Marshall, A. (1891/1920). Principles of Economics. London: Macmillan and Co., Ltd. ${ }^{26}$

Marshall, A. (1898). Distribution and exchange. The Economic Journal, 8(29): 37-59.

McKelvey, B. \& Aldrich, H. (1983). Populations, natural selection, and applied organizational science. Administrative Science Quarterly, 28(1): 101-128.

Mouton, N.T.O. (2009). On the evolution of social scientific metaphors. PhD dissertation, Copenhagen Business School.

\footnotetext{
${ }^{26}$ Facsimile (1891 edition): http://archive.org/stream/principlesecono01marsgoog\#page/n12/mode/2up.
} 
Mouton, N.T.O. (2012). Metaphor and economic thought: A historical perspective. In Soler, H.H. \& White, M.C.W. (eds.), Metaphor and Mills: Figurative Language in Business and Economics. Mouton de Gruyter.

Musolff, A. (2004). Metaphor and conceptual evolution. Metaphorik.de 7: 55-75.

Nerlich, B. \& Clarke, D. (2001). Mind, meaning and metaphor: The philosophy and psychology of metaphor in 19th-Century Germany. History of the Human Sciences, 14: 39-61.

Nisbet, R. (1970). Genealogy, growth, and other metaphors. New Literary History, 1(3): 351-363.

Nisbet, R.A. (1975). Social Change and History: Aspects of the Western Theory of Development. Oxford, UK: Oxford University Press.

Nisbet, R. (2002). Sociology as an Art Form. New Brunswick, Canada: Transaction Publishers.

Oresme, N. (1956). De Moneta: With an Introduction and Notes by Charles Johnson. London: Thomas Nelson and Sons.

Otis, L. (2002). The metaphoric circuit: Organic and technological communication in the Nineteenth Century. Journal of the History of Ideas, 61(1): 105-128.

Pennings, J.M. (1982). Organizational birth frequencies: An empirical investigation. Administrative Science Quarterly. 27(1): 120-144.

Pepper, S.C. (1928). Philosophy and metaphor. The Journal of Philosophy. 25(5): 130-132.

Pepper, S.C. (1935). The root of metaphor theory of metaphysics. The Journal of Philosophy. 32(14): 365-374

Perelman, C. \& Olbrechts-Tyteca, L. (2000 [1969]) The New Rhetoric: A Treatise on Argumentation. Notre Dame, IN, USA: University of Notre Dame Press.

Plato. Collected Dialogues. Hamilton, E. \& Cairns, H. (eds.) Princeton, NJ, USA: Princeton University Press.

Plutarch (1803). Plutarch's Lives, Vol II. Langhorne, J. \& Langhorne, W. (tr.). Edinburgh: Mandell \& Son. ${ }^{27}$

Radcliffe-Brown, A.R. (1935). On the concept of function in social science. American Anthropologist, 37(3): 394.

Richards, I.A. (2001 [1936]). The Philosophy of Rhetoric. London: Routledge.

Rohrer, T. (2006). Three dogmas of embodiment: Cognitive linguistics as a cognitive science. In Kristiansen, G. (ed.), Cognitive Linguistics: Current Applications and Future Perspectives (Vol. I of Applications of Cognitive Linguistics). Berlin: Mouton de Gruyter.

Rousseau, J.-J. (1997). The Social Contract and Other Later Political Writings. Gourevitch, V. (ed.), Cambridge, UK: University Press.

Salisbury (John of) (1963). Policraticus, Dickinson, J. (tr.). New York: Russell \& Russell.

Salisbury (John of) (1991). Policraticus. Nederman, C.J. (ed./tr.). Cambridge, UK: Cambridge University Press.

\footnotetext{
${ }^{27}$ Facsimile: https://play.google.com/store/books/details?id=NIOZAAAAYAAJ\&source=gbs api.
} 
Schön, D. (1963). Displacement of Concepts. Tavistock Publications.

Sewell, W.H. (1997). Geertz, cultural systems, and history: From synchrony to transformation. Representations, 59: 35-55.

Shakespeare, W. (2000). Coriolanus, Bliss, L. (ed.). Cambridge: Cambridge University Press.

Shanon, B. (1992). Metaphor: From fixedness and selection to differentiation and creation. Poetics Today, 13(4): 659-685.

Sinha, C. (1999). Grounding, mapping, and acts of meaning. In Jansen, T. \& Redeker, G. (eds.), Cognitive Linguistics: Foundations, Scope, and Methodology. Mouton de Gruyter.

Spencer, H. (1851). Social Statics: Or the Conditions Essential to Human Happiness Specified, and the First of Them Developed. London: John Chapman. ${ }^{28}$

Spencer, H. (1873). The Study of Sociology. London: Henry S. King. ${ }^{29}$

Spencer, H. (1996 [1891]). Essays: Scientific, Political and Speculative. (12 Volumes). London: Routledge. ${ }^{30}$

Turner, M. \& Fauconnier, G. (1995). Conceptual integration and formal expression. Metaphor and Symbolic Activity, 10(3): 183-203.

Violi, P. (2008). Beyond the body: Towards a full embodied semiosis. In Frank, R.M., Dirven, R., Ziemke, T. \& Bernardez, E. (eds.), Body, Language, and Mind. Volume 2: Sociocultural Situatedness. Mouton de Gruyter.

Ward, L.F. (1895). Contributions to social philosophy: Sociology and biology. The American Journal of Sociology, 1(3): 313-326.

Ward, L.F. (1897). Review: Organisme Et Societe (Rene Worms); La Pathologie Sociale (Paul De Lilienfeld). The American Journal of Sociology, 3(2): 258-264.

Ward, L.F. (1902). Contemporary sociology. The American Journal of Sociology, 7(4): 475-500.

Ward, L.F. (1907). Social and biological struggles. The American Journal of Sociology, 13(3): 289299.

Wolf, E. (1997). Europe and the People Without History. University of California Press.

Zinken, J., Hellsten, I. \& Nerlich, B. (2008). Discourse metaphors. In Frank, R.M., Dirven, R., Ziemke, T. \& Bernardez, E. (eds.). Body, Language, and Mind. Volume 2: Sociocultural Situatedness. Mouton de Gruyter.

\footnotetext{
${ }^{28}$ Facsimile: http://archive.org/stream/socialstaticsor08spengoog\#page/n8/mode/2up.

${ }^{29}$ Facsimile (1874 US edition): http://archive.org/stream/studysociology01spengoog\#page/n4/mode/2up.

${ }^{30}$ Facsimile (1891 edition): http://archive.org/stream/essaysscientific01spenuoft\#page/264/mode/2up.
} 